\title{
Global emission projections for the transportation sector using dynamic technology modeling
}

\author{
F. Yan ${ }^{1,2}$, E. Winijkul ${ }^{1,3}$, D. G. Streets ${ }^{1,2}$, Z. Lu ${ }^{1,2}$, T. C. Bond ${ }^{3}$, and Y. Zhang ${ }^{4}$ \\ ${ }^{1}$ Decision and Information Sciences Division, Argonne National Laboratory, Argonne, IL 60439, USA \\ ${ }^{2}$ Computation Institute, University of Chicago, Chicago, IL 60637, USA \\ ${ }^{3}$ Department of Civil and Environmental Engineering, University of Illinois at Urbana-Champaign, Urbana, IL 61801, USA \\ ${ }^{4}$ Department of Marine, Earth, and Atmospheric Sciences, North Carolina State University, Raleigh, NC 27695, USA \\ Correspondence to: F. Yan (fangyan@anl.gov)
}

Received: 31 July 2013 - Published in Atmos. Chem. Phys. Discuss.: 5 September 2013

Revised: 24 April 2014 - Accepted: 28 April 2014 - Published: 10 June 2014

\begin{abstract}
In this study, global emissions of gases and particles from the transportation sector are projected from the year 2010 to 2050. The Speciated Pollutant Emission Wizard (SPEW)-Trend model, a dynamic model that links the emitter population to its emission characteristics, is used to project emissions from on-road vehicles and non-road engines. Unlike previous models of global emission estimates, SPEW-Trend incorporates considerable detail on the technology stock and builds explicit relationships between socioeconomic drivers and technological changes, such that the vehicle fleet and the vehicle technology shares change dynamically in response to economic development. Emissions from shipping, aviation, and rail are estimated based on other studies so that the final results encompass the entire transportation sector. The emission projections are driven by four commonly-used IPCC (Intergovernmental Panel on Climate Change) scenarios (A1B, A2, B1, and B2). With global fossil-fuel use (oil and coal) in the transportation sector in the range of 128-171 EJ across the four scenarios, global emissions are projected to be $101-138 \mathrm{Tg}$ of carbon monoxide (CO), 44-54 Tg of nitrogen oxides $\left(\mathrm{NO}_{\mathrm{x}}\right), 14-18 \mathrm{Tg}$ of nonmethane total hydrocarbons (THC), and 3.6-4.4 Tg of particulate matter (PM) in the year 2030. At the global level, a common feature of the emission scenarios is a projected decline in emissions during the first one or two decades (20102030), because the effects of stringent emission standards offset the growth in fuel use. Emissions increase slightly in some scenarios after 2030, because of the fast growth of onroad vehicles with lax or no emission standards in Africa and increasing emissions from non-road gasoline engines
\end{abstract}

and shipping. On-road vehicles and non-road engines contribute the most to global $\mathrm{CO}$ and THC emissions, while on-road vehicles and shipping contribute the most to $\mathrm{NO}_{\mathrm{x}}$ and PM emissions. At the regional level, Latin America and East Asia are the two largest contributors to global $\mathrm{CO}$ and THC emissions in the year 2010; this dominance shifts to Africa and South Asia in the future. By the year 2050, for CO and THC emissions, non-road engines contribute the greatest fraction in Asia and the former USSR, while on-road vehicles make the largest contribution in Latin America, Africa, and the Middle East; for $\mathrm{NO}_{\mathrm{x}}$ and $\mathrm{PM}$ emissions, shipping controls the trend in most regions. These forecasts include a formal treatment of the factors that drive technology choices in the global vehicle sector and therefore represent a robust and plausible projection of what future emissions may be. These results have important implications for emissions of gases and aerosols that influence air quality, human health, and climate change.

\section{Introduction}

\subsection{Emission projections}

Global emission projections are critical elements in understanding future climate impacts at global and regional scales. They provide support to forecasts of future climate change, intercontinental transport of air pollutants, and the evolution of the entire Earth system, and they are the basis for determining the benefits of possible mitigation strategies (Levy et 
al., 2008; Shindell et al., 2011; Streets et al., 2004, 2009). Such projections must cover emissions at a multinational scale and be consistent across different regions of the world (Borken et al., 2007). The requirement of consistency across time and space makes the projection of emissions challenging, because it means applying the most current understanding of the factors that drive emissions at local and national scales to the world's regions.

Unlike emission projections of energy-related species such as carbon dioxide $\left(\mathrm{CO}_{2}\right)$, which depend to a large extent only on the amounts of fuel consumed and the carbon content of the fuel (Nakicenovic et al., 2000; Smith, 2005), emission projections of other important anthropogenic species such as nitrogen oxides $\left(\mathrm{NO}_{\mathrm{x}}\right)$, carbon monoxide $(\mathrm{CO})$, non-methane total hydrocarbons (THC), and particulate matter (PM) require consideration of technology choices, because different technologies can yield widely varying emission rates (Cooke and Wilson, 1996; Bond et al., 2004, 2007; Streets et al., 2004; Cofala et al., 2007; Klimont et al., 2002, 2009; van Aardenne et al., 1999; Ohara et al., 2007). "Technology" here is defined as a piece of hardware or an operating procedure that influences the emission factor of an emitter. The net change of emissions over time can then be characterized by changes of technology shares. Emission factors depend on technology improvements, which in turn may be related to economic growth, but a more important factor is environmental legislation and the degree to which it is enforced. In developing regions, there is no certainty that emission standards will be enforced, and this adds to uncertainty in the emission projections. Environmental legislation can be a key factor in determining the penetration of abatement measures and consequently the evolution of emission factors (Dentener et al., 2010).

The deficiency of current emission projections is that they lack a clear or explicit relationship between socioeconomic factors and projected technology change. Earlier studies (e.g., Streets et al., 2004; Rao et al., 2005; Ohara et al., 2007) realized that emission factors would change with time, but they did not explicitly account for the contribution of technological changes in determining emissions. In previous studies, emissions have often been estimated by combining fuel consumption with an averaged emission factor that represents the whole emitter population. Expert judgment is often used to determine technology shares, and changes of emission factors over time are not always explicitly represented. Such emission estimates cannot represent well the continuous influence of economic development on consumer choice or the introduction of emission control strategies. Therefore, it is essential to differentiate emitters by their emission characteristics and demonstrate the evolution of technology dynamically and consistently across model years and the world's regions.

This work presents a new set of global projections of gaseous and particle emissions from the whole transportation sector. These projections emphasize the role of combus- tion practice and emission control technology in the determination of emissions and reflect the changes of technologies. While Yan et al. (2011) describes the modeling approach to project future emissions in detail, this paper not only broadens the treatment of on-road vehicle emissions from PM to gases, but also includes emissions from non-road engines and adds emissions from shipping, aviation, and rail to provide a comprehensive treatment of transportation sector emissions.

\subsection{Importance of emissions from the transportation sector}

As a key component of economic development and human welfare, transportation activity is increasing rapidly around the world (Uherek et al., 2010; Wang et al., 2006; ICAO/FESG, 2008; Arora et al., 2011; Dargay et al., 2007; Ribeiro et al., 2007). Robust growth in the transportation sector is expected to continue over the next several decades.

This steady growth in energy use makes the transportation sector a crucial driver of future global anthropogenic emissions. On-road vehicles and non-road engines together contribute as much as $41 \%$ of anthropogenic $\mathrm{NO}_{\mathrm{x}}$ emissions (JRC/PBL, 2011). While most sectors decreased their greenhouse gas (GHG) emissions from 1990 to 2010, emissions from transportation increased by nearly $21 \%$ (EEA, 2012b). However, emissions of pollutants closely related to the combustion process, such as $\mathrm{NO}_{\mathrm{x}}, \mathrm{CO}, \mathrm{THC}, \mathrm{PM}$, and sulfur dioxide $\left(\mathrm{SO}_{2}\right)$, have increased at a slower rate than fuel consumption or $\mathrm{CO}_{2}$ emissions, because of improved emission control technologies and fuel quality (Cofala et al., 2007; Rao et al., 2005; Fulton and Eads, 2004; Smith et al., 2005; Lu et al., 2011; Klimont et al., 2009; Zhang et al., 2009).

Emissions from the transportation sector have important effects on air quality, climate, and public health. Several studies have investigated this interaction by specifically isolating the climate forcing from transportation (Fuglestvedt et al., 2008; Berntsen and Fuglestvedt, 2008; Unger et al., 2010; Koffi et al., 2010; Shindell et al., 2011; Saikawa et al., 2011; Balkanski et al., 2010). For example, Fuglestvedt et al. (2008) showed that the transportation sector contributes significantly to man-made radiative forcing (RF) and that current emissions from transportation are responsible for $16 \%$ of the integrated net forcing from all current anthropogenic emissions over the next 100 years. Berntsen and $\mathrm{Fu}-$ glestvedt (2008) estimated that the global average temperature will rise by $0.23 \mathrm{~K}$ if the emissions from the transportation sector remain constant at year-2000 levels. Unger et al. (2010) concluded that on-road vehicles exert the largest net positive RF among all economic sectors in the near term and the second largest in the long term.

The results of this work will provide an improved foundation to better understand future climate and air quality. More importantly, this work should help identify the benefits of making alternative technology and policy choices, under a 
variety of socioeconomic futures, to mitigate the adverse effects of anthropogenic emissions on the global environment.

This paper focuses on the exhaust emissions of gases and particles from the combustion of fossil fuels (oil and coal) in the transportation sector. It includes indirect GHG, such as $\mathrm{CO}, \mathrm{NO}_{\mathrm{x}}$, and $\mathrm{THC}$, which are precursors of tropospheric ozone $\left(\mathrm{O}_{3}\right)$ and affect the oxidation capacity of the atmosphere. It also includes emissions of primary PM, black carbon (BC), and organic carbon (OC) (results for the two carbonaceous species are shown in the Supplement).

The paper is organized as follows: in Sect. 2, we discuss the general approach used to project emissions and describe the Speciated Pollutant Emission Wizard (SPEW)Trend model. Section 3 describes information concerning the fuel-use projections, technology shares, and emission factors for each transportation mode: on-road vehicles, non-road engines, shipping, aviation, and rail. In Sect. 4, we present the model results and compare them with other studies. Section 5 summarizes the major findings and makes recommendations for future research.

\section{Modeling approach}

\subsection{General methodology}

The basic modeling approach in this paper is similar to earlier work (Bond et al., 2004, 2007; Streets et al., 2004), in which emissions are determined by apportioning fuel use among different emitting technology types. An emission factor is assigned to each technology, and the net emissions in any given year are determined by the mix of technologies. Yan et al. (2011) provide a full description of how the mix of technologies is determined dynamically by deriving explicit relationships among socioeconomic factors and technological changes. The schematic methodology is shown in Fig. 1. This process is handled by the SPEW-Trend model and is described in detail in Yan et al. (2011). In this paper, the SPEWTrend model is applied to emission estimates from on-road vehicles and non-road engines. The general equation to represent emissions for scenario $i$, species $j$, and region $k$ is as follows:

$$
\begin{gathered}
\operatorname{Em}_{i, j, k}(t)=\sum_{l} \sum_{m} \sum_{n} \sum_{p} \mathrm{FC}_{i, k, l, m, n}(t) \mathrm{EF}_{j, l, m, p, 0} \\
\mathrm{DR}_{j, l, m, n, t-p},
\end{gathered}
$$

where subscripts $i, j, k, l, m, n$, and $p$ represent scenario, species, region, fuel type (diesel or gasoline), engine type (light-duty or heavy-duty for on-road vehicles; small, medium, or large for non-road engines), technology (or emission standards), and vehicle or engine model year (defined as the year it is manufactured), respectively. $\operatorname{Em}(t)$ is emissions in calendar year $t$. FC is fuel consumption. $\mathrm{EF}_{0}$ is the emission factor specific to each species/fuel/technology at vehicle age zero. $\mathrm{DR}_{t-p}$ is the degradation rate of the emission fac-

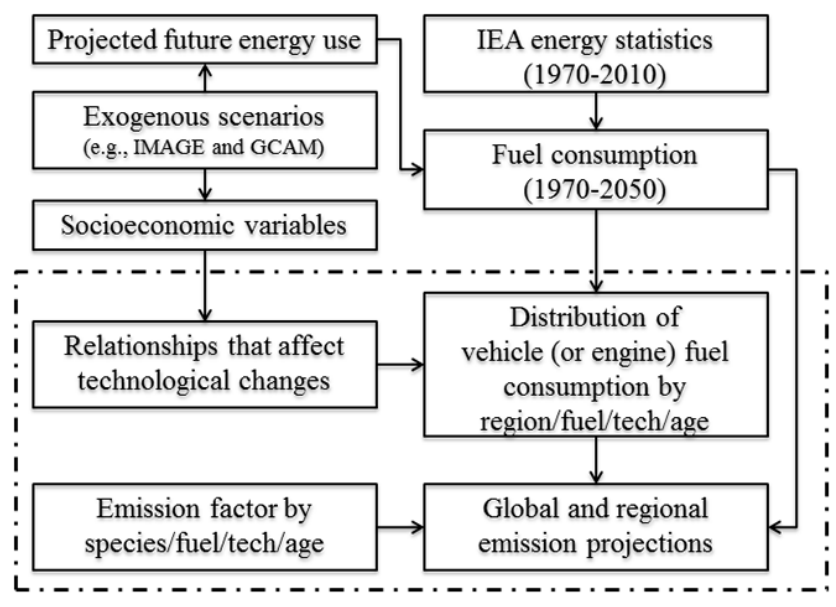

Figure 1. Schematic methodology for developing projections of exhaust emissions from on-road vehicles and non-road engines. Parts in the dashed rectangular box are handled by the SPEW-Trend model. The exogenous scenarios are from an integrated assessment model framework.

tor of the vehicle at age $(t-p)$, and $\mathrm{DR}=1$ for vehicle at age zero; here, the degradation rate is defined as the relative increase rate in emission factor with time or usage (Ubanwa et al., 2003).

As shown in Fig. 1, historical fuel consumption estimates are based on fuel statistics, e.g., as compiled by the International Energy Agency (IEA). Estimates of future fuel consumption are based on exogenous scenarios that have been simulated in integrated assessment models (van $\mathrm{Vu}-$ uren et al., 2006) such as the Integrated Model to Assess the Global Environment (IMAGE) (RIVM, 2001; MNP, 2006) and the Global Change Assessment Model (GCAM) (Smith and Wigley, 2006), so that the emission estimates are driven by the same "big picture" factors as other energy-related emission scenarios (Nakicenovic et al., 2000). Socioeconomic variables from these exogenous scenarios are used to derive the relationships that affect technological changes. Both historical and future fuel use are disaggregated by the SPEW-Trend model (shown in the dashed rectangular box in Fig. 1) into heterogeneous emitter groups based on fuel, engine type, technology, and age. The details of fuel projections and technology splits have been discussed in Yan et al. (2011), and they are briefly summarized in Sects. 2.2 and 3 .

For shipping, aviation, and rail, many studies have described future emission scenarios (e.g., Eyring et al., 2005a, b, 2010; Corbett et al., 2010; Endresen et al., 2007; Buhaug et al., 2009; Paxian et al., 2010; Lee et al., 2009, 2010; Owen et al., 2010; Sausen and Schumann, 2000; Eyers et al., 2004; Bek and Sorenson, 1998; Berghof et al., 2005; EEA, 2012a; Uherek et al., 2010). We estimate emissions from these three transportation modes by combining information on fuel consumption and emission factors from a variety of published 
data sources. No explicit technological changes for these three transportation modes are considered in this work. Total emissions are estimated by time-dependent, fleet-average emission factors obtained from other studies, which represent technological changes implicitly. Trends toward cleaner technologies are represented as changes of average emission factors with time. Emissions from shipping, aviation, and rail are estimated as

$\operatorname{Em}_{i, j, k}(t)=\sum_{l} \mathrm{FC}_{i, k, l} \mathrm{EF}_{\mathrm{avg}, j, l}(t)$.

We assign emission characteristics for 17 world regions: Canada, USA, Central America, South America, North Africa, West Africa, East Africa, OECD (Organisation for European Economic Co-operation) Europe, Eastern Europe, former USSR, Middle East, South Asia, East Asia, Southeast Asia, Oceania, and Japan. They are sometimes regrouped to 10 regions for ease of presentation or for comparison with other studies (Table S1 in the Supplement). Emissions are projected from 2010 to 2050 and presented annually. Available data of historical fuel consumption ends in 2010. In order to evaluate and compare with other studies, past emissions from 1990 are also shown in some figures.

\subsection{Dynamic technology model: SPEW-Trend}

As shown in Fig. 1 and introduced in Sect. 2.1, we estimate emissions from on-road vehicles and non-road engines within the framework of the SPEW-Trend model. As a hybridization of a bottom-up engineering model and a topdown economic model, SPEW-Trend can be driven by any economic model, as long as it provides the required inputs. In this work, we apply four scenarios (A1B, A2, B1 and B2), developed for the Intergovernmental Panel on Climate Change (IPCC) Special Report on Emission Scenarios (SRES) (Nakicenovic et al., 2000), as formulated by the IMAGE group (RIVM, 2001). These scenarios were used as the basis of the IPCC Third Assessment Report (TAR) and the fourth (AR4). We take fuel consumption, population, and GDP (gross domestic product) from the SRES scenarios.

Emissions decrease with the introduction of advanced technology and the implementation of more-stringent environmental regulations (Cofala et al., 2007; Klimont et al., 2002; Bond et al., 2004; Streets et al., 2004; Rao et al., 2005). In SPEW-Trend, we group vehicles built to a single emission standard as one "technology". Although different control approaches are sometimes used to meet the same emission standard, they have the same effect on emission factor. Emissions may also increase with aging (Ubanwa et al., 2003), or even achieve extremely high values under malfunctioning conditions ("superemitters"). Superemitters refer to vehicles that are responsible for a relatively large fraction of air pollutant emissions from the transportation sector, even though they may only represent a small portion of the vehicle fleet (Lawson et al., 1993; Hansen and Rosen, 1990; Zhang et al., 1995;
Ban-Weiss et al., 2009; Bluett et al., 2008; Wang et al., 2011). Superemitters are also treated as technology variants in this work.

Major features of the SPEW-Trend model are summarized here, and equations that describe each of the governing relationships are given in Table 1. In particular (1) future annual fuel consumption is set by exogenous scenarios; (2) new vehicle demand is set by growth in fuel consumption and the need for vehicle replacement (secondary markets for used vehicles are not considered in this work); (3) retirement rates depend on regional income rates and on-road vehicle age or non-road engine cumulative service hours (Table 1, "retirement rate/survival rate", and Fig. S1a in the Supplement); (4) the technology for new vehicles introduced in any year is set by the emission standard in force in that year, so that the time at which vehicles with advanced emission standards enter the population is region-dependent (Table 1, "Adoption of emission standards"); (5) the fraction of normal emitters that become superemitters is based on vehicle age (Table 1, "superemitter transition rate", and Fig. S1b in the Supplement); and (6) the emission factors of individual vehicles (except superemitters) change as the vehicle ages and experiences three phases: first, no change (for on-road vehicles) or increasing slowly to emission-standard level (for non-road engines), then increasing to maximal level, and finally flattening out (Table 1, "degradation rate", and Fig. S1c in the Supplement). In this paper, we assume that fleet dynamic changes follow historical patterns, in the absence of evidence to the contrary. Any air-quality regulations other than the implementation of emission standards are not considered in this paper. The effectiveness of additional emission reduction programs, such as inspection and maintenance regimes, will be explored in future work.

\section{Fuel projections, technology divisions, and emission factors}

\subsection{On-road vehicles}

\subsubsection{Fuel consumption}

To estimate gaseous emissions from on-road vehicles, this work applies the same set of fuel use and socioeconomic variables as was used in Yan et al. (2011) to estimate PM emissions. Though fuel use for on-road vehicles is presently available to 2010 from the IEA, we apply IEA fuel data only until 2005 in order to be consistent with Yan et al. (2011). On-road vehicles are divided into three categories: lightduty gasoline vehicles (LDGV), light-duty diesel vehicles (LDDV), and heavy-duty diesel (HDDV) vehicles. The following assumptions are made for historical and future onroad fuel consumption: (1) historical fuel use up to 2005 is from IEA and is consistent with Yan et al. (2011); (2) gasoline is consumed by LDGVs, and the growth rate after 2005 
Table 1. Relationships and parameters used in the SPEW-Trend model for on-road vehicles and non-road engines.

\begin{tabular}{|c|c|c|c|}
\hline Relationship & Parameter & \multicolumn{2}{|l|}{ Description } \\
\hline Survival rate $(\mathrm{Su})^{\mathrm{a}, \mathrm{b}}$ & $\begin{array}{l}s^{\mathrm{c}} \\
\alpha_{\text {ret }}^{\mathrm{d}} \\
L_{50, \text { ret }} \\
\beta_{1}^{\mathrm{d}} \\
\beta_{2}^{\mathrm{d}}\end{array}$ & \multicolumn{2}{|c|}{$\begin{array}{l}\text { Age (or cumulative service hours) } \\
\text { Intercept, shape factor related to the onset of significant retirement } \\
\text { Median age or median service hours at which } 50 \% \text { of the vehicles are retired } \\
\text { Age coefficient } \\
\text { Income coefficient }\end{array}$} \\
\hline Adoption of emission standards & \multicolumn{3}{|c|}{$\begin{array}{l}\text { First year when advanced emission standards (Euro I or US Tier 1) are applied } \\
\text { Time intervals between emission standard introduction }\end{array}$} \\
\hline $\begin{array}{l}\text { Superemitter } \\
\text { transition rate }(\mathrm{Tr})^{\mathrm{f}}\end{array}$ & $\begin{array}{l}\alpha_{\text {sup }}^{\mathrm{g}} \\
L_{50, \text { sup }}^{\mathrm{g}} \\
\text { gaing }\end{array}$ & \multicolumn{2}{|c|}{$\begin{array}{l}\text { Shape factor; determines slope of the curve } \\
\text { Vehicle life at which the rate becomes half of the maximum } \\
\text { Maximum rate of superemitter transition }\end{array}$} \\
\hline Degradation rate $(\mathrm{DR})^{\mathrm{h}}$ & $\begin{array}{l}\mathrm{EF}_{\text {new }} \\
\mathrm{EF}_{\mathrm{es}} \\
\mathrm{EF}_{\text {max }} \\
s_{\text {deg }} \\
s_{\text {stab }}\end{array}$ & \multicolumn{2}{|c|}{$\begin{array}{l}\text { Emission factor for new vehicles } \\
\text { Emission factor, the same as emission stan } \\
\text { Maximum emission factor } \\
\text { Age that emission factor starts to degrade } \\
\text { Age that emission factor starts to stabilize }\end{array}$} \\
\hline \multicolumn{4}{|c|}{$\begin{array}{l}\text { b Survival rate can be converted to a retirement rate as } \operatorname{Re}(s)=1-\frac{\mathrm{Su}(s+1)}{\mathrm{Su}(s)} \text {. } \\
\mathrm{c} s \text { represents vehicle age of on-road vehicles or cumulative service hours of non-road engines. } \\
\mathrm{d} \text { For LDVs, } \alpha_{\text {ret }}=5.34, \beta_{1}=-0.24 \text {, and } \beta_{2}=-0.029 \text {. For HDVs, } \alpha_{\text {ret }}=4.93, \beta_{1}=-0.15 \text {, and } \beta_{2}=-0.078 \text {. } \\
\text { e Income level is represented by the ratio of local and global GDP per capita, rgdp. }\end{array}$} \\
\hline \multicolumn{4}{|c|}{$\begin{array}{l}\mathrm{f} \text { The transition rate is defined as the fraction of normal vehicles that become superemitters in any given year: } \operatorname{Tr}(s)=\frac{\text { gain }}{1+\exp \left[\alpha_{\text {sup }}\left(1-s / L_{50, \text { sup }}\right)\right]} \\
\mathrm{g}_{\alpha_{\text {sup }}}=5.5, L_{50 \text {,sup }}=5.0 \text {, and gain }=0.032 \text {. }\end{array}$} \\
\hline 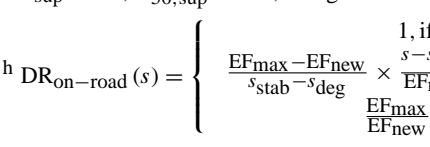 & $\begin{array}{l}s \leq s_{\text {deg }} \\
\frac{\text { eg }}{\text { ww }}+1, \text { if } s_{\text {deg }} \\
\text { if } s \geq s_{\text {stab }}\end{array}$ & $\mathrm{DR}_{\text {non-road }}(s)=$ & 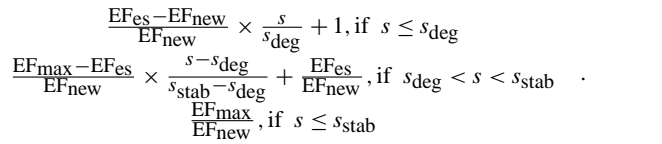 \\
\hline
\end{tabular}

follows the growth rate of transportation light oil in IMAGE; (3) diesel is consumed by both LDDVs and HDDVs, and the growth rate after 2005 follows the growth rate of transportation heavy oil in IMAGE; (4) a constant ratio of fuel use by LDDVs and LDGVs is used to estimate diesel use by LDDVs, and the regionally dependent ratios are from the IEA/SMP (Sustainable Mobility Project) transport model for the year 2000; and (5) HDDVs consume the rest of the diesel. The composition of the light-duty fleet may in fact change, and this contributes some uncertainty to total emissions, especially for $\mathrm{CO}$ and THC, which are dominated by LDGVs. We summarize the above assumptions about historical and future fuel use in Table S2 in the Supplement.

\subsubsection{Major relationships}

While the assumptions about modeling on-road emission projections within the framework of SPEW-Trend were discussed extensively in Yan et al. (2011), this section briefly summarizes the essential details, including retirement rate, implementation of emission standards, degradation rate, and superemitter transition rate.

\section{Retirement rate}

Based on extensive investigations of the literature on vehicle retirement (e.g., Parks, 1979; Greenspan and Cohen, 1999), two main factors are chosen to determine retirement rate: vehicle age and the balance between vehicle cost and vehicle repair. The latter factor is dependent on regional income level and is represented by the ratio of regional and global GDP per capita. The equations used to determine retirement rate are shown in the footnote of Table 1, and the parameters are derived from vehicle fleet information. Figure S1a in the Supplement shows examples of survival rates corresponding to different income levels.

\section{Implementation of emission standards}

Two emission standards sequences - "Tier" in the US, and "Euro" in Europe - capture most of the regulatory transitions observed around the world. The coefficients of GDP per capita were found in Yan et al. (2011) to be not significant in the study of Cox proportional-hazard regression (Cox, 1972), 
if only technology-following countries were included, and were only significant if technology-forcing countries were included. Therefore, an empirical method is applied to estimate the implementation dates of standards in different world regions for past and future years. Tables S6, S7, and S8 in the Supplement show the detailed assumptions and projected adoption dates of emission standards. This work assumes that once standards are implemented the effectiveness of those standards is the same across the whole region. This might underestimate emissions in regions where regulatory enforcement and inspection are weak. Also, no further emission controls beyond Tier 2 or Euro VI (or equivalent emission standards) are considered in this work. This assumption may slightly overestimate emissions after 2030 when all regions except Africa have implemented Tier 2 or Euro VI.

\section{Degradation rate}

The general pattern of degradation rate is modified from Ubanwa et al. (2003). Figure S1c presents an example of PM emission factor degradation for on-road LDDV under the Euro I standard, showing three phases: new engine (constant), degradation (increasing linearly), and stabilized (staying constant at the maximum level). The interplay among degradation rate, retirement rate, and timing of new emission standards varies among regions and therefore leads to regionally differentiated average emission factors in any given year, as shown in Fig. S1d in the Supplement, which presents the average PM emission factors of all LDDVs following Euro I in two regions.

\section{Superemitter transition rate}

The number of superemitters is determined by a superemitter transition rate (shown in the footnote of Table 1 and Fig. S1b in the Supplement), which represents the rate at which normal vehicles become superemitters. The number of superemitters in the vehicle fleet at a given time, like any component of the vehicle population, depends on the balance between introduction and retirement. Based on our assumptions about transition rate, in each calendar year some fraction of vehicles of all model years has the possibility to develop into superemitters, depending on their ages. This determines the rate of introduction of superemitters into the vehicle fleet. And, just like for normal vehicles, superemitters retire from the fleet at a rate estimated by regional income level and vehicle age. Thus, the number of existing superemitters in a given year is determined by the survived superemitters from the previous year, as well as the introduction and retirement of superemitters in the study year. We use a term called "equilibrium superemitter fraction" to represent the total contribution of superemitters of all model ages, no matter what emission standards they originally come from. The parameters are chosen so that the equilibrium values of su- peremitter fraction are approximately the same as those used in Bond et al. (2004), which assumed that the central value of equilibrium superemitter fraction is $5 \%$ for the US and similar regions, $20 \%$ for Asia, Latin America and Africa, and $10 \%$ for Eastern Europe and the former USSR. We use these central values in this work and uncertainty ranges are presented in Bond et al. (2004). Figure S2 in the Supplement shows equilibrium superemitter fractions of HDDVs in different regions between 2010 and 2050. Though previous efforts have been made to identify superemitters (Bishop and Stedman, 2008; Ban-Weiss et al., 2009; Subramanian et al., 2009; Smit and Bluett, 2011; Borken-Kleefeld et al., 2012), there is still a lack of agreement about the appropriate representation and fraction values of superemitters. In this work, we choose to apply a modified logistic function and one set of parameters in superemitter transition rate for all regions, in order to make the model globally consistent. The choice of parameters relies on the assumptions of Bond et al. (2004). For a more refined treatment of superemitters and their fractional contribution to the vehicle fleet, more measurements of different vehicle types with various emission standards and model years are necessary. This will require additional vehicle testing protocols and experiments with greater data sharing among research institutions and laboratories and regulatory agencies.

\subsubsection{Emission factors}

Because of the complexity of ensuring representative vehicle samples and driving conditions, obtaining appropriate emission factors for vehicles with different technologies is difficult, even with extensive measurement programs. Dynamometer tests are widely used to measure vehicle emissions, but their disadvantage is that they only measure a few vehicles over a small range of conditions which may not be representative of the in-use fleet and actual driving cycles. Traffic tunnel and remote sensing measurements are valuable, but they only catch a snapshot of many vehicles at limited locations, where all of the tested vehicles are operated at similar speeds and acceleration profiles (Yanowitz et al., 2000). There is no procedure that measures the full spectrum of vehicles and conditions. In spite of the fact that dynamometer tests can be biased toward lower emissions by excluding high-emission conditions, driver behavior, and heavily loaded vehicles (Bond et al., 2004; Subramanian et al., 2009), this work mostly relies on emission factor measurements from dynamometer tests. Measurements from tunnel testing and remote sensing are not used directly due to their constraints on locations and circumstances.

Our basic approach to resolving emission factors consists of the following four steps: (1) determining emission factors for new vehicles based on measurements from regions where the stringent US or European emission standards have already been implemented; (2) if measurements under the more advanced standards (e.g., Euro V and VI and US standards 
Table 2. Gaseous emission factors (unit: $\mathrm{g} \mathrm{kg}^{-1}$ ) and degradation rates for LDGVs.

\begin{tabular}{|c|c|c|c|c|c|c|c|c|c|c|}
\hline $\begin{array}{l}\text { Emission } \\
\text { standards }\end{array}$ & $s_{\mathrm{deg}} / s_{\mathrm{stab}}^{\mathrm{u}}$ & $\mathrm{EF}_{\text {new }}$ & $\begin{array}{c}\mathrm{CO} \\
\mathrm{DR}_{\max }^{1, \mathrm{~m}, \mathrm{n}}\end{array}$ & $\mathrm{EF}_{\max }$ & $\mathrm{EF}_{\text {new }}$ & $\begin{array}{c}\mathrm{THC} \\
\mathrm{DR}_{\max }^{1, \mathrm{~m}}\end{array}$ & $\mathrm{EF}_{\max }$ & $\mathrm{EF}_{\text {new }}$ & $\begin{array}{c}\mathrm{NO}_{\mathrm{x}} \\
\mathrm{DR}_{\text {max }}^{1, \mathrm{~m}}\end{array}$ & $\mathrm{EF}_{\max }$ \\
\hline Tier 1 & $1 / 11$ & $19.6^{\mathrm{d}}$ & 3.15 & 61.9 & $1.35^{\circ}$ & $3.15^{\mathrm{p}}$ & 4.27 & $1.97^{\circ}$ & $2.20^{\mathrm{j}}$ & 4.33 \\
\hline $\mathrm{NLEV}^{\mathrm{a}}$ & $1 / 11$ & $10.3^{\mathrm{e}}$ & 3.72 & 38.3 & $1.13^{\mathrm{j}}$ & $3.72^{\mathrm{p}}$ & 4.21 & $1.19^{\mathrm{q}}$ & $2.02^{q}$ & 2.41 \\
\hline Tier 2-2004 & $1 / 11$ & $7.07^{\mathrm{e}}$ & 3.17 & 22.4 & $0.39^{q}$ & $3.17^{\mathrm{q}}$ & 1.23 & $0.52^{q}$ & $2.26^{\mathrm{q}}$ & 1.17 \\
\hline Tier 2-2006 & $1 / 11$ & $6.43^{\mathrm{e}}$ & 3.17 & 20.4 & $0.34^{\mathrm{q}}$ & $3.17 \mathrm{q}$ & 1.09 & $0.34^{\mathrm{q}}$ & $2.26^{\mathrm{q}}$ & 0.77 \\
\hline Tier2-2007 & $1 / 11$ & $6.39^{\mathrm{e}}$ & 3.17 & 20.3 & $0.36^{\mathrm{q}}$ & $3.17^{\mathrm{q}}$ & 1.13 & $0.26^{\mathrm{q}}$ & $2.26^{\mathrm{q}}$ & 0.59 \\
\hline Euro I & $1 / 11$ & $39.1^{\mathrm{f}}$ & 3.15 & 123 & $4.73^{f}$ & $3.15^{\mathrm{r}}$ & 14.91 & $4.45^{\mathrm{f}}$ & $2.20^{\mathrm{r}}$ & 9.80 \\
\hline Euro II & $1 / 11$ & $24.4^{\mathrm{f}}$ & 3.15 & 76.8 & $2.40^{f}$ & $3.15^{\mathrm{r}}$ & 7.56 & $2.35^{f}$ & $2.20^{r}$ & 5.18 \\
\hline Euro III & $1 / 11$ & $25.6^{\mathrm{f}}$ & 3.15 & 80.8 & $1.41^{\mathrm{f}}$ & $3.15^{\mathrm{r}}$ & 4.45 & $1.39^{\mathrm{f}}$ & $2.20^{r}$ & 3.06 \\
\hline Euro IV & $1 / 11$ & $9.85^{f}$ & 3.17 & 31.2 & $0.87^{\mathrm{f}}$ & $3.17^{\mathrm{s}}$ & 2.75 & $0.80^{\mathrm{f}}$ & $2.26^{\mathrm{S}}$ & 1.81 \\
\hline Euro V & $1 / 11$ & $9.85^{\mathrm{g}}$ & 3.17 & 31.2 & $0.87^{\mathrm{g}}$ & $3.17^{\mathrm{s}}$ & 2.75 & $0.60^{\mathrm{g}}$ & $2.26^{\mathrm{S}}$ & 1.36 \\
\hline Euro VI & $1 / 11$ & $9.85^{\mathrm{g}}$ & 3.17 & 31.2 & $0.87^{\mathrm{g}}$ & $3.17^{\mathrm{s}}$ & 2.75 & $0.60^{\mathrm{g}}$ & $2.26^{\mathrm{S}}$ & 1.36 \\
\hline None & $1 / 11$ & $408^{\mathrm{h}}$ & 1.28 & 521 & $39.0^{\mathrm{h}}$ & $1.28^{\mathrm{t}}$ & 49.8 & $25.6^{\mathrm{h}}$ & $2.20^{\mathrm{j}}$ & 56.3 \\
\hline OPAC & $1 / 11$ & $159^{\mathrm{h}}$ & 2.59 & 413 & $21.5^{\mathrm{h}}$ & $2.59^{t}$ & 55.7 & $18.1^{\mathrm{h}}$ & $2.20^{\mathrm{j}}$ & 39.8 \\
\hline Super $1^{b}$ & - & $521^{\mathrm{i}, \mathrm{k}}$ & - & - & $63.9^{\mathrm{i}, \mathrm{k}}$ & - & - & $56.3^{\mathrm{i}, \mathrm{k}}$ & - & - \\
\hline Super $2^{c}$ & - & $123^{\mathrm{j}, \mathrm{k}}$ & - & - & $29.1^{\mathrm{j}, \mathrm{k}}$ & - & - & $9.80^{\mathrm{j}, \mathrm{k}}$ & - & - \\
\hline
\end{tabular}

${ }^{a}$ National Low Emission Vehicle program; ${ }^{b}$ refers to superemitters that were originally vehicles without regulation (none) and with opacity standards $(\mathrm{OPAC}) ;{ }^{\mathrm{c}}$ refers to superemitters that were originally vehicles with US Tier 1 and 2, and Euro I-VI standards; ${ }^{\mathrm{d}}$ Maricq et al. (1999); US EPA (2011); ${ }^{\mathrm{e}}$ US EPA (2011); ${ }^{\mathrm{f}}$ Ntziachristos and Samaras (2001); EEA (2012a); ${ }^{\mathrm{g}}$ based on emission standard reduction rate (Ntziachristos and Samaras, 2001; Yan et al., 2011). ${ }^{\mathrm{h}}$ EEA (2012a); US EPA (2012a); ${ }^{\mathrm{i}}$ Durbin et al. (1999); Cadle et al. (1999); ${ }^{\mathrm{j}}$ Durbin et al. (1999); ${ }^{\mathrm{k}}$ maximal of references and highest emission factors for corresponding vehicle groups. ${ }^{l} \mathrm{DR}_{\max }=\mathrm{EF}_{\max } / \mathrm{EF}_{\text {new }} ;{ }^{\mathrm{m}}$ ages that vehicles start to degrade and stabilize are the same as for PM (Yan et al., 2011); ${ }^{\mathrm{n}}$ the same as THC; ${ }^{\mathrm{o}}$ Maricq et al. (1999); US EPA (2011, 2012a); ${ }^{\mathrm{p}}$ US EPA (2011, 2012a); ${ }^{\mathrm{q}}$ US EPA (2011); ${ }^{\mathrm{r}}$ the same as Tier $1{ }^{\mathrm{s}}$ the same as Tier $2 ;{ }^{t}$ US EPA (2012a). ${ }^{u} s_{\text {deg }}$ is the age at which vehicle emission factors start to increase; $s_{\text {stab }}$ is the age at which vehicle emission factors start to be stabilized.

after 2010) are not available, then estimation of emission factors is based on the assumption that the ratio between two standards represents an achievable emission reduction (Ntziachristos and Samaras, 2001; Yan et al., 2011); (3) deriving degradation rates from measurements that take into account vehicle age or model year; and (4) estimating emission factors for superemitters by averaging the emission factors of "smokers", poorly maintained vehicles, or the emission factors of the highest 5-10\% of vehicles.

Tables 2, 3, and 4 summarize gaseous emission factors and degradation rates for on-road vehicles under US and European emission standards, based on measurement programs and compiled reports (Cadle et al., 1999; Durbin et al., 1999; EEA, 2012a; Maricq et al., 1999; McCormick et al., 2003; Ntziachristos and Samaras, 2001; US EPA, 2009, 2011, 2012a; Yan et al., 2011; Yanowitz et al., 2000). Emission factors for PM were previously presented in Yan et al. (2011), and they are not repeated in this paper. Since there is incomplete information about gaseous emissions, we make several assumptions as shown below. First, the years in which emission factors for $\mathrm{CO}, \mathrm{NO}_{\mathrm{x}}$, and THC start to increase or stabilize are the same as for PM (Ubanwa et al., 2003), but the degradation rates are different (see Fig. S1c in the Supplement for the general patterns of degradation rate). Second, $\mathrm{CO}, \mathrm{NO}_{\mathrm{x}}, \mathrm{THC}$, and PM share the same fraction of superemitters, but a particular vehicle is not necessarily a superemitter of all pollutants. The increase of emis- sion factors for superemitters is not the same for all vehicles. Some studies (McClintock, 2007) showed that the fraction of superemitters depends on pollutants. Third, the degradation rates for THC and CO are the same for LDGVs because they are related products of incomplete combustion. Finally, $\mathrm{NO}_{\mathrm{x}}$ emission factors for diesel vehicles with standards between opacity and Euro VI (or equivalent) are constant over their lifetime. With the introduction of aftertreatment systems to meet regulatory requirements for Euro VI or other similar standards, tampering and poor maintenance are expected to significantly increase emissions over the vehicle lifetime, as compared with the emissions of a new vehicle (US EPA, 2009). Because most measurements of emission factors have been carried out in the US or European countries, it is necessary to make expert judgments about emission factors and degradation rates in regions where direct measurements are not available. As more measurements become available, we plan to update the emission factors, degradation rates, and aging effects used in this study.

\subsection{Non-road engines}

\subsubsection{Fuel consumption}

Similar to our treatment of fuel consumption for on-road vehicles, we use historical fuel consumption for non-road engines from IEA (2012a, b) and project future fuel consumption based on IPCC scenarios. Non-road gasoline and 
Table 3. Gaseous emission factors (unit: $\mathrm{g} \mathrm{kg}^{-1}$ ) and degradation rates for LDDVs.

\begin{tabular}{|c|c|c|c|c|c|c|c|c|c|c|}
\hline \multirow{2}{*}{$\begin{array}{l}\text { Emission } \\
\text { standards }\end{array}$} & \multirow[t]{2}{*}{$s_{\mathrm{deg}} / s_{\mathrm{stab}}{ }^{\mathrm{n}}$} & \multicolumn{3}{|c|}{$\mathrm{CO}$} & \multicolumn{3}{|c|}{ THC } & \multicolumn{3}{|c|}{$\mathrm{NO}_{\mathrm{x}}$} \\
\hline & & $\mathrm{EF}_{\text {new }}$ & $D R_{\max }^{i, j}$ & $\mathrm{EF}_{\text {max }}$ & $\mathrm{EF}_{\text {new }}$ & $\mathrm{DR}_{\max }^{\mathrm{i}, \mathrm{j}}$ & $\mathrm{EF}_{\max }$ & $\mathrm{EF}_{\text {new }}$ & $\mathrm{DR}_{\max }^{\mathrm{i}, \mathrm{j}}$ & $\mathrm{EF}_{\max }$ \\
\hline Tier 1 & $2 / 11$ & $11.5^{\mathrm{d}}$ & $1.17^{\mathrm{k}}$ & 13.4 & $1.52^{\mathrm{d}}$ & $1.31^{\mathrm{k}}$ & 2.00 & $10.5^{\mathrm{d}}$ & $1.00^{1}$ & 10.5 \\
\hline NLEV $^{\mathrm{a}}$ & $2 / 11$ & $11.5^{\mathrm{d}}$ & $1.17^{\mathrm{k}}$ & 13.4 & $1.52^{\mathrm{d}}$ & $1.31^{\mathrm{k}}$ & 2.00 & $10.5^{\mathrm{d}}$ & $1.00^{1}$ & 10.5 \\
\hline Tier 2-2004 & $2 / 11$ & $11.5^{\mathrm{d}}$ & $1.17^{\mathrm{k}}$ & 13.4 & $1.52^{\mathrm{d}}$ & $1.31^{\mathrm{k}}$ & 2.00 & $10.5^{\mathrm{d}}$ & $1.00^{1}$ & 10.5 \\
\hline Tier 2-2006 & $2 / 11$ & $3.70^{\mathrm{d}}$ & $1.17^{\mathrm{k}}$ & 4.32 & $0.17^{\mathrm{d}}$ & $1.31^{\mathrm{k}}$ & 0.22 & $3.71^{\mathrm{d}}$ & $1.00^{1}$ & 3.71 \\
\hline Tier2-2007 & $2 / 11$ & $3.70^{\mathrm{d}}$ & $1.17^{\mathrm{k}}$ & 4.32 & $0.17^{\mathrm{d}}$ & $1.31^{\mathrm{k}}$ & 0.22 & $3.71^{\mathrm{d}}$ & $1.80^{\mathrm{m}}$ & 6.65 \\
\hline Euro I & $2 / 11$ & $8.03^{\mathrm{e}}$ & $1.17^{\mathrm{k}}$ & 9.37 & $1.68^{\mathrm{e}}$ & $1.31^{\mathrm{k}}$ & 2.20 & $9.52^{\mathrm{e}}$ & $1.00^{1}$ & 9.52 \\
\hline Euro II & $2 / 11$ & $7.42^{\mathrm{e}}$ & $1.17^{\mathrm{k}}$ & 8.65 & $1.69^{\mathrm{e}}$ & $1.31^{\mathrm{k}}$ & 2.22 & $9.70^{\mathrm{e}}$ & $1.00^{1}$ & 9.70 \\
\hline Euro III & $2 / 11$ & $5.45^{\mathrm{e}}$ & $1.17^{\mathrm{k}}$ & 6.35 & $0.98^{\mathrm{e}}$ & $1.31^{\mathrm{k}}$ & 1.28 & $8.95^{\mathrm{e}}$ & $1.00^{1}$ & 8.95 \\
\hline Euro IV & $2 / 11$ & $4.74^{\mathrm{e}}$ & $1.17^{\mathrm{k}}$ & 5.53 & $0.51^{\mathrm{e}}$ & $1.31^{\mathrm{k}}$ & 0.66 & $5.34^{\mathrm{e}}$ & $1.00^{1}$ & 5.34 \\
\hline Euro V & $2 / 11$ & $2.59^{\mathrm{f}}$ & $1.17^{\mathrm{k}}$ & 3.02 & $0.25^{\mathrm{f}}$ & $1.31^{\mathrm{k}}$ & 0.32 & $4.84^{\mathrm{f}}$ & $1.00^{1}$ & 4.84 \\
\hline Euro VI & $2 / 11$ & $2.59^{\mathrm{f}}$ & $1.17^{\mathrm{k}}$ & 3.02 & $0.14^{\mathrm{f}}$ & $1.31^{\mathrm{k}}$ & 0.18 & $1.55^{\mathrm{f}}$ & $1.80^{\mathrm{m}}$ & 2.78 \\
\hline None & $2 / 11$ & $17.1^{\mathrm{g}}$ & $1.17^{\mathrm{k}}$ & 20.0 & $6.15^{\mathrm{g}}$ & $1.31^{\mathrm{k}}$ & 8.07 & $12.9^{\mathrm{g}}$ & $1.08^{\mathrm{k}}$ & 13.9 \\
\hline OPAC & $2 / 11$ & $12.1^{\mathrm{g}}$ & $1.17^{\mathrm{k}}$ & 12.5 & $2.56^{\mathrm{g}}$ & $1.31^{\mathrm{k}}$ & 3.36 & $11.1^{\mathrm{g}}$ & $1.08^{\mathrm{k}}$ & 12.0 \\
\hline Super $1^{b}$ & - & $20.0^{\mathrm{h}}$ & - & - & $8.07^{\mathrm{h}}$ & - & - & $13.9^{\mathrm{h}}$ & - & - \\
\hline Super $2^{\mathrm{c}}$ & - & $13.4^{\mathrm{h}}$ & - & - & $2.22^{\mathrm{h}}$ & - & - & $10.5^{\mathrm{h}}$ & - & - \\
\hline
\end{tabular}

a National Low Emission Vehicle program; ${ }^{\mathrm{b}}$ refers to superemitters that were originally vehicles without standards (none), and with opacity, Tier 1 and Euro I standards; ${ }^{c}$ refers to superemitters that were originally vehicles with US Tier 2 and Euro II-VI standards; ${ }^{d}$ US EPA (2011);

${ }^{\mathrm{e}}$ Ntziachristos and Samaras (2001); EEA (2012a); ${ }^{\mathrm{f}}$ EEA (2012a); $\mathrm{g}$ EEA (2012a); US EPA (2011, 2012a); ${ }^{\mathrm{h}}$ maximal value of highest emission factors for corresponding vehicle groups; ${ }^{i} \mathrm{DR}_{\max }=\mathrm{EF}_{\max } / \mathrm{EF}_{\text {new }} ;{ }^{j}$ ages that vehicles start to degrade and stabilize are the same as PM (Yan et al., 2011); ${ }^{\mathrm{k}} \mathrm{US}$ EPA (2012a); ${ }^{1}$ no degradation; ${ }^{\mathrm{m}}$ the same as the emission factor for the HDDV Euro VI standard; ${ }^{\mathrm{n}} s_{\text {deg }}$ is the age at which vehicle emission factors start to increase; $s_{\text {stab }}$ is the age at which vehicle emission factors start to be stabilized.

diesel engines used in agriculture, construction and mining, and industry are included in this category. Historical diesel consumption up to 2010 in the agriculture/forestry, industry, and construction and mining (CM) sectors from IEA (2012a, b) is used. Gasoline consumption, however, is not available for most countries. We calculate the ratios between diesel and gasoline fuel for each region from countries where both diesel and gasoline fuels are available and use these ratios to estimate gasoline consumption.

For the industrial and CM sectors, future fuel use follows the growth rates from IMAGE after 2010. For the agricultural sector, where future fuel use is subsumed in other sectors in IMAGE, fuel consumption is estimated by developing relationships between agricultural diesel fuel consumption per crop area (diesel fuel intensity) and agriculture GDP per crop area (agricultural productivity).

\subsubsection{Population model and emission factors}

The principles used in the technology modeling approach for non-road engines are the same as those described by Yan et al. (2011) for on-road vehicles. The derivation of the parameters required for calculation of non-road emissions is discussed in this section. Because emissions from non-road engines are closely related to their power (or engine size), non-road engines are grouped into three subgroups for both diesel engines (large, medium, and small engines) and gasoline engines (high power 4-stroke, low power 4-stroke, and
2 -stroke engines). These groups are consistent with the categories used in US and European Union emission standards (Dieselnet, 2012; US EPA, 2012b).

\section{Retirement rates}

Following the approach used to model on-road vehicles, we use a logistic function to fit the scrappage curve provided by the US EPA (2005). As listed in Table 1, survival rate ( $\mathrm{Su}$ ) is a function of cumulative service $(s)$ for non-road engines:

$\operatorname{Su}(s)=\frac{1}{1+\exp \left[\alpha_{\text {ret }}\left(s / L_{50, \text { ret }}-1\right)\right]}$,

where $\alpha_{\text {ret }}$ is acquired from curve fitting of the scrappage rate

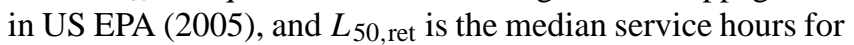
non-road engines.

Cumulative service $(s)$ is the total engine operation time, in hours, accumulated over the life of the engine (US EPA, 2010a). In SPEW-Trend, we specify the annual service and keep track of the cumulative service as the engine ages. Annual service hours are determined based on engine size (small, medium, large, 2-stroke, low power 4-stroke, and high power 4-stroke engines) and type (industrial, construction and mining, agriculture). Annual service data are developed based on data in the NONROAD model (US EPA, 2010a) and EEA (2012a). Median service hours $\left(L_{50, \text { ret }}\right)$ are the cumulative service at which $50 \%$ of the engines have 
Table 4. Gaseous emission factors (unit: $\mathrm{g} \mathrm{kg}^{-1}$ ) and degradation rates for HDDVs.

\begin{tabular}{|c|c|c|c|c|c|c|c|c|c|c|}
\hline \multirow{2}{*}{$\begin{array}{l}\text { Emission } \\
\text { standards }\end{array}$} & \multirow[t]{2}{*}{$s_{\mathrm{deg}} / s_{\mathrm{stab}}{ }^{\mathrm{r}}$} & \multicolumn{3}{|c|}{$\mathrm{CO}$} & \multicolumn{3}{|c|}{ THC } & \multicolumn{3}{|c|}{$\mathrm{NO}_{\mathrm{x}}$} \\
\hline & & $\mathrm{EF}_{\text {new }}$ & $\mathrm{DR}_{\max }^{\mathrm{h}, \mathrm{i}}$ & $\mathrm{EF}_{\max }$ & $\mathrm{EF}_{\text {new }}$ & $\mathrm{DR}_{\max }^{\mathrm{h}, \mathrm{i}}$ & $\mathrm{EF}_{\max }$ & $\mathrm{EF}_{\text {new }}$ & $\mathrm{DR}_{\max }^{\mathrm{h}, \mathrm{i}}$ & $\mathrm{EF}_{\max }$ \\
\hline 1988 & $2 / 13$ & $14.5^{\mathrm{c}}$ & $3.34^{\mathrm{j}}$ & 48.5 & $2.02^{\mathrm{c}}$ & $4.00^{j}$ & 8.09 & $36.1^{c}$ & $1.00^{\mathrm{q}}$ & 36.1 \\
\hline 1991 & $2 / 9$ & $10.1^{\mathrm{c}}$ & $4.00^{\mathrm{k}}$ & 40.4 & $2.43^{\mathrm{c}}$ & $4.00^{\mathrm{k}}$ & 9.73 & $34.8^{\mathrm{c}}$ & $1.00^{\mathrm{q}}$ & 34.8 \\
\hline 1993 & $2 / 9$ & $8.06^{\mathrm{c}}$ & $4.00^{\mathrm{k}}$ & 32.2 & $1.28^{\mathrm{c}}$ & $4.00^{\mathrm{k}}$ & 5.12 & $29.9^{c}$ & $1.00^{\mathrm{q}}$ & 29.9 \\
\hline 1994 & $2 / 8$ & $6.43^{c}$ & $4.00^{\mathrm{k}}$ & 25.7 & $1.27^{\mathrm{c}}$ & $4.00^{\mathrm{k}}$ & 5.09 & $36.9^{c}$ & $1.00^{\mathrm{k}}$ & 36.9 \\
\hline 1996 & $2 / 8$ & $7.87^{\mathrm{c}}$ & $4.00^{\mathrm{k}}$ & 31.5 & $0.23^{\mathrm{c}}$ & $4.00^{\mathrm{k}}$ & 0.93 & $27.9^{c}$ & $1.00^{\mathrm{k}}$ & 27.9 \\
\hline 1998 & $2 / 8$ & $7.87^{d}$ & $4.00^{\mathrm{k}}$ & 31.5 & $0.23^{\mathrm{d}}$ & $4.00^{\mathrm{k}}$ & 0.93 & $22.3^{d}$ & $1.00^{\mathrm{k}}$ & 22.3 \\
\hline 2004 & $2 / 8$ & $7.87^{d}$ & $2.50^{\mathrm{k}}$ & 19.7 & $0.23^{\mathrm{d}}$ & $2.50^{\mathrm{k}}$ & 0.58 & $13.4^{\mathrm{d}}$ & $1.00^{\mathrm{k}}$ & 13.4 \\
\hline 2007 & $2 / 8$ & $7.87^{d}$ & $2.50^{\mathrm{k}}$ & 19.7 & $0.02^{\mathrm{d}}$ & $2.50^{\mathrm{k}}$ & 0.06 & $6.69^{d}$ & $1.00^{\mathrm{k}}$ & 6.69 \\
\hline 2010 & $2 / 8$ & $7.87^{d}$ & $1.33^{\mathrm{k}}$ & 10.5 & $0.02^{\mathrm{d}}$ & $1.33^{\mathrm{k}}$ & 0.03 & $1.12^{\mathrm{d}}$ & $1.80^{\mathrm{k}}$ & 2.00 \\
\hline Euro I & $2 / 9$ & $7.01^{\mathrm{e}}$ & $4.00^{1}$ & 28.0 & $2.46^{\mathrm{e}}$ & $4.00^{1}$ & 9.85 & $34.9^{\mathrm{e}}$ & $1.00^{1}$ & 34.9 \\
\hline Euro II & $2 / 8$ & $6.11^{\mathrm{e}}$ & $4.00^{1}$ & 24.4 & $1.65^{\mathrm{e}}$ & $4.00^{1}$ & 6.59 & $36.3^{\mathrm{e}}$ & $1.00^{1}$ & 36.3 \\
\hline Euro III & $2 / 8$ & $6.57^{\mathrm{e}}$ & $4.00^{1}$ & 26.3 & $1.56^{\mathrm{e}}$ & $4.00^{1}$ & 6.24 & $28.3^{\mathrm{e}}$ & $1.00^{1}$ & 28.3 \\
\hline Euro IV & $2 / 8$ & $0.48^{\mathrm{e}}$ & $2.50^{\mathrm{m}}$ & 1.19 & $0.07^{\mathrm{e}}$ & $2.50^{\mathrm{m}}$ & 0.18 & $19.9^{\mathrm{e}}$ & $1.00^{\mathrm{m}}$ & 19.9 \\
\hline Euro V & $2 / 8$ & $0.48^{\mathrm{e}}$ & $2.50^{\mathrm{m}}$ & 1.19 & $0.07^{\mathrm{e}}$ & $2.50^{\mathrm{m}}$ & 0.18 & $9.96^{\mathrm{e}}$ & $1.00^{\mathrm{m}}$ & 9.96 \\
\hline Euro VI & $2 / 8$ & $0.48^{\mathrm{e}}$ & $1.33^{\mathrm{n}}$ & 0.63 & $0.07^{\mathrm{e}}$ & $1.33^{\mathrm{n}}$ & 0.09 & $1.92^{\mathrm{e}}$ & $1.80^{\mathrm{n}}$ & 3.45 \\
\hline None & $2 / 13$ & $17.5^{\mathrm{c}}$ & $2.94^{\mathrm{j}}$ & 51.5 & $6.91^{\circ}$ & $1.84^{\mathrm{j}}$ & 12.7 & $45.7^{\circ}$ & $1.04^{\mathrm{q}}$ & 47.7 \\
\hline OPAC & $2 / 13$ & $16.0^{\mathrm{c}}$ & $3.12^{\mathrm{j}}$ & 50.0 & $4.47^{\circ}$ & $2.33^{j}$ & 10.4 & $40.6^{\circ}$ & $1.02^{\mathrm{q}}$ & 41.3 \\
\hline Super $1^{\mathrm{a}}$ & - & $62.7^{\mathrm{f}, \mathrm{g}}$ & - & - & $12.7^{\mathrm{f}}$ & - & - & $55.5^{\mathrm{f}}$ & - & - \\
\hline Super $2^{b}$ & - & $31.5^{\mathrm{c}, \mathrm{g}}$ & - & - & $6.59^{c}$ & - & - & $55.5^{p}$ & - & - \\
\hline
\end{tabular}

a Refers to superemitters that were originally vehicles without standards, and with opacity, US HDDV 1988-1993 and Euro I standards; ${ }^{\mathrm{b}}$ refers to superemitters that were originally vehicles with US HDDV 1994-2010 and Euro II-VI standards; ${ }^{c}$ Yanowitz et al. (2004); ${ }^{d}$ based on emission standard reduction rate (Ntziachristos and Samaras, 2001; Yan et al., 2011). ${ }^{\mathrm{e}}$ EEA (2012a); ${ }^{\mathrm{f}}$ Yanowitz et al. (2000); McCormick et al. (2003); ${ }^{\mathrm{g}}$ maximal of references and highest emission factors for corresponding vehicle groups; ${ }^{\mathrm{h}} \mathrm{DR}_{\max }=\mathrm{EF}_{\max } / \mathrm{EF}_{\text {new }} ;{ }^{\mathrm{i}}$ ages that vehicles start to degrade and stabilize are the same as PM (Yan et al., 2011); ${ }^{j}$ estimated by applying average of emission degradation $\left(\mathrm{g} \mathrm{kg}^{-1} \mathrm{year}^{-1}\right.$ ) for US HDDV standards from 1991 to $1998 ;{ }^{k}$ US EPA (2009); ${ }^{1}$ the same as the emission factor for the US HDDV 1991 standard; ${ }^{m}$ the same as the emission factor for the US HDDV 2004 standard; $^{\mathrm{n}}$ the same as the emission factor for the US HDDV 2010 standard; ${ }^{\circ}$ EEA (2012a); Yanowitz et al. (2000); ${ }^{\mathrm{p}}$ the same as the emission factor for Super $1 ;{ }^{\mathrm{q}}$ US EPA (2012a); ${ }^{\mathrm{r}} s_{\text {deg }}$ is the age at which vehicle emission factors start to increase; $s_{\text {stab }}$ is the age at which vehicle emission factors start to be stabilized.

retired. We use the median service hours of different engine sizes in the US (US EPA, 2010a). As for on-road vehicles (Yan et al., 2011), we assume that the median service hours depend on the ratio of regional and global GDP per capita. A linear relationship is derived between median service hours and the ratio of GDP per capita based on available data in several countries (Japan, Korea, India, Brazil, Egypt, Argentina, and the US). This relationship is used to estimate the survival rates in regions without observations.

\section{Implementation of emission standards}

Few countries have regulated emission standards for nonroad engines. Two well-known sets of emission standards for diesel engines are used in the US ("Tiers") and Europe ("Stages"). Other regions have elected to follow the US (Canada, Central America, and South Asia) or European (other regions) progression, although with different implementation schedules. For regions without any plans for nonroad emission standards, we assume that emission standards for diesel engines will be implemented 20 years after the emission standards of HDDVs. The first emission standard for non-road diesel engines is projected to be implemented in 2015 in South America, Eastern Europe, and Oceania (as soon as possible considering that no implementation plans exist in these regions in 2013). Emission standards for nonroad gasoline engines have already been implemented for all engine sizes in the US (US EPA, 2012b) and for small engines in Europe, Canada, and Australia. The US standards are known as "Phase 1", "Phase 2", and "Phase 3". In regions without emission standards for non-road gasoline engines, we assume that the standards will be implemented in the same year as that for non-road diesel engines. The exception is that high power 4-stroke gasoline engines are assumed to be regulated 7 years after the first gasoline standard, based on the standard schedule in the US.

\section{Emission factors for new engines}

There are very limited emission testing data available for non-road engines. Moreover, most available emission factor measurements are for engines without emission standards (EEA, 2012a; US EPA 2010b); those for future engines with advanced emission standards are mostly not available. For 
new diesel engines without standards, we average emission factors corresponding to engine sizes from the EEA (2012a) and US EPA (2010b), while emission factors for Tier 1 and Stage I engines are from the US EPA (2010b). For new gasoline engines, we estimate emission factors for new engines without standards and for Phase 1 standards based on data sets in the US EPA (2012b). We use reduction factors (Ntziachristos and Samaras, 2001) to estimate the appropriate emission factors for new engines under tighter emission standards, using the same methodology that was developed for on-road vehicles in Yan et al. (2011).

\section{Degradation rates}

Similar to on-road vehicles, emission factors for non-road engines (except superemitters) are separated into three phases (EEA, 2012a; US EPA, 2010b; US EPA, 2010c) including durability, degradation, and stabilizing phases. Figure S1c in the Supplement shows an example of PM emission factor degradation for agricultural medium diesel engines under the Stage I standard. The difference for non-road engines is that the first phase (durability phase) includes periods when the emission factors increase from new-engine emission levels to the highest level without exceeding the standards, because these engines are still under emission warranty (US EPA, $2012 b$ ) and non-road emission standards require emissions of aged engines to be lower than standards during specific periods (US EPA, 2010b, c). Emission factors for on-road vehicles, however, remain the same as those for new engines in the first phase. In the degradation phase, non-road engines degrade at either the same or a higher rate. Finally, emission factors stabilize until they reach the maximal values for normal engines.

\section{Superemitter emission rates}

The superemitter transition rate is represented by a logistic function, as shown in the footnote of Table 1. The parameters are chosen by comparing the superemitter population estimated by Bond et al. (2004). We assume that emission factors for non-road superemitters have the same characteristics as those for on-road superemitters, since there has been little emissions testing of non-road engines. The basic assumption is that the emission factor ratio between superemitters and normal non-road engines under the first level of emission standards (e.g., Tier 1 and Stage I) is the same as that for on-road vehicles. Emission factors for superemitters are assumed to be much higher than normal engines and constant throughout the study period.

\subsection{Shipping}

\subsubsection{Fuel consumption}

The IEA database contains records of regional demand for (or sale of) heavy fuel oil (HFO) and marine distillate oil (MDO) in three categories: international marine bunkers, domestic navigation, and fishing. However, recent studies that have focused on activity-based estimates of energy and power demands from fundamental principles (Eyring et al., 2005a, 2010; Buhaug et al., 2009; Corbett and Koehler, 2003; Endresen et al., 2007) questioned the validity of relying on the statistics of marine and fuel sales. Buhaug et al. (2009) compared the world's fleet fuel consumption from different activity-based estimates (Corbett and Koehler, 2003; Endresen et al., 2007; Eyring et al., 2005a, b) and statistics (EIA, 2012; IEA, 2012a, b), and noted that IEA substantially underreports shipping fuel consumption. By comparing country and regional levels over time, Smith et al. (2011) argued that the energy discrepancies among different estimates can be explained by the IEA "standard error" category. There is no other consumption category in the IEA data that is large enough to include the difference between the regional bunker fuel consumption estimate and the IEAreported bunker fuel use. While we presume that the difference is unreported consumption, no adjustment to the IEA consumption data has been made for historical emission estimates. Despite of awareness of the underestimates, we still use IEA data sets to make sure that the source of historical fuel consumption is consistent with other transport modes; for this reason, it is possible that shipping emissions in this work may be underestimated.

We increase the global shipping fuel consumption (including international shipping, domestic shipping, and fishing, but excluding military vessels) from current to future by applying information from Eyring et al. (2005b). Their work determined future ship-traffic demand from the economic growth forecasts according to the IPCC SRES storylines. In Eyring et al. (2005b), fuel consumption is projected through extrapolation of historical trends in economic growth, total seaborne trade, and number of ships, as well as the average installed power per ship. We employ the annual-average growth rates of global shipping fuel consumption in years 2030 and 2050 from Eyring et al. (2005b) to construct trajectories from current IEA fuel use that vary by region. We distribute the global fuel use to the 17 world regions by applying a simple linear relationship between growth of fuel and regional GDP (Fulton and Eads, 2004; MNP, 2006; RIVM, 2001). Data sources and the major equations used to project shipping fuel consumption are summarized in Table S3 in the Supplement. 


\subsubsection{Emission factors}

Emission estimates must take into account the variation in operational and technical changes over the years (Eyring, 2005a, b, 2010; Endresen et al., 2007). Ships need to meet an increasing number of rules, regulations, and voluntary appeals from international, national, and local regulatory bodies, such as MARPOL (International Convention for the Prevention of Marine Pollution from Ships) Annex VI by the IMO (International Maritime Organization) (IMO, 2009).

Emission reduction technologies are mainly available for exhaust pollutants. The highest $\mathrm{NO}_{\mathrm{x}}$ reduction can be achieved with selective catalytic reduction (SCR). Significant reduction of $\mathrm{SO}_{2}$ emissions can be achieved through limitations on the sulfur content of fuels and an exhaust-gas scrubbing system. Emissions of PM can be reduced by scrubbing with seawater and/or by optimizing combustion conditions. Aftertreatment technologies that are used for on-road and non-road engines to reduce PM emissions, such as diesel particle filters, are not suitable for marine fuels due to their high sulfur content (Buhaug et al., 2009). Engine exhaust emissions of hydrocarbons are relatively low, and they can be reduced by optimizing the combustion process and using oxidation catalysts for low-sulfur fuel (IMO, 2009). Technologies that reduce these pollutants can interact with other technologies, however. For example, when SCR technology is adopted to reduce $\mathrm{NO}_{\mathrm{x}}$ emissions, low-sulfur fuels are required and PM emissions are reduced as well (Eyring et al., 2005b).

In this work, we use fleet-average emission factors to estimate emissions. We do not distribute shipping engines by vessel speed, engine power, duty cycle, or emission control technologies, but rely on integrated fleet information from other studies. Eyring et al. (2005b) presented four technology scenarios; we choose the business-as-usual scenario (TS4), which represents a future in which the sulfur content of marine fuels is still rather high, $\mathrm{NO}_{\mathrm{x}}$ emission standards are adopted in all new engines according to current IMO regulations, but there is no shift to alternative fuels. In this work, we assume that changes of fleet composition are the same as $\mathrm{TS} 4$, and the average reductions of emission factors due to introduction of cleaner technologies are the same as well. As shown in Table 5, emission factors in 2000 and before are back-calculated with fuel consumption and total emissions from Table 3 of Eyring et al. (2010), which summarized information from a variety of sources (Endresen et al., 2007; Eyring, 2005a, b; Fearnleys, 2007).

\subsection{Aviation}

Historical and current emissions from aviation have previously been assessed in terms of the construction of threedimensional gridded inventories, such as those constructed for the early 1990s air traffic and reviewed by Henderson et al. (1999). Other inventories have been developed, such as
Table 5. Emission factors (unit: $\mathrm{g} \mathrm{kg}^{-1}$ ) for shipping, aviation, and rail.

\begin{tabular}{ll|rrrr}
\hline \multicolumn{2}{c|}{ Transport modes } & $\mathrm{CO}$ & $\mathrm{NO}_{\mathrm{x}}$ & $\mathrm{THC}$ & $\mathrm{PM}$ \\
\hline \multirow{3}{*}{ Shipping (oil) $^{\mathrm{n}}$} & $2000^{\mathrm{a}, \mathrm{b}}$ & 4.72 & $71.0^{\mathrm{d}}$ & $5.12^{\mathrm{e}}$ & 5.6 \\
& $2020^{\mathrm{c}, \mathrm{b}}$ & 4.72 & $56.8^{\mathrm{d}}$ & $4.89^{\mathrm{e}}$ & 5.32 \\
& $2050^{\mathrm{c}, \mathrm{b}}$ & 4.72 & $49.7^{\mathrm{d}}$ & $4.66^{\mathrm{e}}$ & 5.04 \\
\hline \multirow{3}{*}{ Aviation (oil) $^{\mathrm{n}}$} & 2000 & $10.0^{\mathrm{f}}$ & $13.6^{\mathrm{g}}$ & $1.80^{\mathrm{f}}$ & $0.025^{\mathrm{i}}$ \\
& 2020 & $6.54^{\mathrm{f}}$ & $11.9^{\mathrm{g}}$ & $0.91^{\mathrm{f}}$ & $0.025^{\mathrm{i}}$ \\
& 2050 & $3.44^{\mathrm{f}}$ & $9.79 / 11.5 /$ & $0.33^{\mathrm{f}}$ & $0.025^{\mathrm{i}}$ \\
& & & $7.98 / 10.1^{\mathrm{g}, \mathrm{h}}$ & & \\
\hline \multirow{4}{*}{ Rail (oil) } & & & & \\
& No control & 11.8 & 69.5 & 8.95 & 4.62 \\
& Stage I & 11.2 & 34.2 & 5.81 & 3.08 \\
& Stage II & 9.89 & 31.1 & 4.74 & 2.31 \\
& Stage IIIA & 5.30 & 28.6 & 3.58 & 0.69 \\
& Stage IIIB & 4.24 & 20.3 & 3.58 & 0.14 \\
& Stage IV & 4.24 & 13.4 & 3.40 & 0.28 \\
\hline Rail (Coal) & & & & \\
& & $4.20^{\mathrm{l}}$ & $8.40^{\mathrm{l}}$ & $0.84^{\mathrm{l}}$ & $15.0^{\mathrm{d}}$ \\
\hline
\end{tabular}

a Estimated by fuel consumption and emissions in Table 3, Eyring et al. (2010); ${ }^{\mathrm{b}}$ emission factors before 2000 are the same as these in 2000 except $\mathrm{NO}_{\mathrm{x}}$; emission factors in 2000-2020 and 2020-2050 are interpolated linearly; ${ }^{\mathrm{c}}$ emission factors in 2020 and 2050 and estimated by emission factors in 2000 and technology reduction factors in scenario TS4 in Eyring et al. (2005b); ${ }^{\mathrm{d}} \mathrm{NO}_{\mathrm{x}}$ emission factor before 1999 is the same as the one in $1995\left(80.4 \mathrm{~g} \mathrm{~kg}^{-1}\right)$, it decreases linearly from 1995 to $2000 ;{ }^{\mathrm{e}}$ no HC emissions from crude oil transport; ${ }^{\mathrm{f}}$ emission factors in 1976, 1984, and 1992 from NASA emission inventories in Baughcum et al. (1999) are applied to fit an exponential curve $[y=\exp (a x+b)]$, where $x$ is calendar year and $y$ is emission factor, and then use the estimated parameters to model emission factors in other years. The parameters for $\mathrm{CO}$ are $a=-0.0214$, and $b=45.082$, those for THC are: $a=-0.0338$, and $b=68.198, \mathrm{~g}$ estimated by emissions and fuel consumption in Owen factors in year 2050 are distinguished by scenarios due to different trends of technology; ${ }^{\mathrm{h}}$ for scenario A1B, A2, B1, and B2, respectively; ${ }^{\mathrm{i}}$ Table 1 in Lee et al. (2010); ${ }^{\mathrm{j}}$ GAINS (Klimont et al., 2009); ${ }^{\mathrm{k}}$ coal emission factors are assumed to be constant; as coal makes a small contribution in the future rail energy use, this assumption will not affect the total transportation emission much. ${ }^{1}$ Uherek et al. (2010); ${ }^{\mathrm{m}}$ Bond et al. (2004); ${ }^{\mathrm{n}}$ fleet average emission factors.

AERO2k (Eyers et al., 2004), FAST (Lee et al., 2005), and SAGE (Kim et al., 2007). Lee et al. (2010) summarized recent results from these and older models for emissions of the 1990s.

Future emission scenarios were first constructed by Henderson et al. (1999) based on GDP projections under older IPCC scenarios. Following similar methods, Owen and Lee (2006), as well as Berghof et al. (2005) for CONSAVE, projected emissions with updated scenarios. Lee et al. (2009) showed that IEA fuel sales data consistently indicate larger $\mathrm{CO}_{2}$ emissions than are implied by "bottom-up" inventories, which include less or no information about military aviation, aviation gasoline, non-scheduled traffic, holding patterns, and the effect of winds (Lee et al., 2009; Owen et al., 2010). The most recent aviation emission scenarios were developed by Owen et al. (2010), which relied on air traffic projections of ICAO/CAEP (ICAO/FESG, 2008) and a simple econometric model based on global GDP growth as the principal driver (Olsthoorn, 2001; Vedantham and Oppenheimer, 1998).

In this work, we apply historical regional and global fuel consumption data from IEA (2012a, b) and future global fuel growth rates from Owen et al. (2010). The details are summarized in Table S4 in the Supplement. Similar to fuel consumption for shipping, future global aviation fuel use is distributed among the world's regions based on regional fuel fractions 
as well as a linear relationship between fuel growth and GDP (Baughcum et al., 1999; Fulton and Eads, 2004; MNP, 2006; RIVM, 2001). Table 5 shows fleet-average emission factors for aviation in the years 2000, 2020, and 2050. Emission factors for $\mathrm{NO}_{\mathrm{x}}$ are back-calculated using emissions and fuel consumption in Owen et al. (2010) and they are assumed to be constant in the year 2000 and before, as there was no consideration of $\mathrm{NO}_{\mathrm{x}}$ control in this period. We take historical emission factors for THC and $\mathrm{CO}$ from the emission inventory of Baughcum et al. (1999) and fit them with an exponential curve to estimate emission factors in the other years. Emission factors of $\mathrm{PM}$ and $\mathrm{SO}_{2}$ are taken directly from Lee et al. (2010).

\subsection{Rail}

Rail is likely to play a key role in future transportation policies. This is because rail has lower emissions and higher energy efficiency per passenger and per quantity of freight carried than other modes (Uherek et al., 2010; EEA, 2004). Studies in Europe have shown that rail emissions make up only $1-3 \%$ of total emissions (EEA, 2004; European Commission, 2007). Electricity contributes about $30 \%$ of final energy for global rail transportation; and this share is $50 \%$ in the European Union. The remaining energy sources are fossil fuels, such as coal, middle distillate oil, and residual fuel oil. With the transition from coal to oil, coal-driven trains are only common in China these days, and their number is declining there as well. Global coal consumption by rail has been reduced from $49 \mathrm{Mt}$ in 1980 to $6 \mathrm{Mt}$ in 2010 (Uherek et al., 2010; IEA, 2012a, b).

Rail fuel data are available for all the world's regions at the country level from the IEA for the period 1971-2010. For future fuel use, we exploit the growth of GDP to project diesel oil growth. Passenger and freight rail are considered separately, due to their different elasticity to GDP and energy intensity. Information about passenger and freight fuel share, fuel growth elasticity to GDP growth, annual energy intensity improvement, and electricity fraction comes from Fulton and Eads (2004). Because coal still contributes significantly in China, we apply a transition curve between coal and oil to split energy for rail by applying the same parameters as in Bond et al. (2007). We assume that oil contributes $100 \%$ to rail fuel demand in other regions after 2010. Table S5 in the Supplement lists detailed information, assumptions, and data sources about fuel consumption from rail.

Rail diesel engines produced after 1990 emit substantially less $\mathrm{NO}_{\mathrm{x}}$ and $\mathrm{PM}$ compared to older engines, particularly in the US and European countries (Bergin et al., 2012; UIC, 2006). In the US, the first set of emission standards, named Tier 0, applied to rail engines manufactured from 1973 to 2001, which was then followed by Tier 1 for engines manufactured from 2002 to 2004, and Tier 2 for those after 2005. Within Europe, emissions from rail engines are regulated by the non-road mobile machinery (NRMM) directives.
The GAINS (Greenhouse Gas and Air Pollution Interactions and Synergies) model provides diesel emission factors for rail by different control levels, as shown in Table 5. Instead of distributing rail engines by emission standards or control technologies, we use the fleet-average emission factors from GAINS to combine with fuel consumption to estimate total emissions. As GAINS only provides emission estimates at 5-year intervals to 2030, fleet-average emission factors are interpolated to get annual estimates. We assume that all rail engines will achieve more stringent control levels in the year 2050 than 2030. Coal emission factors are taken from the IPCC, Uherek et al. (2010), and Bond et al. (2004) and are summarized in Table 5.

\section{Results and discussion}

\subsection{Global emissions}

Estimated global fuel consumption and emissions of $\mathrm{CO}$, $\mathrm{NO}_{\mathrm{x}}$, THC, and PM from 2000 to 2050 for the entire transportation sector under all scenarios are shown in the left panel of Fig. 2. The middle panel of Fig. 2 presents fuel consumption and emissions by transport mode under scenario A1B; these depictions for the other three scenarios are shown in Fig. S3 in the Supplement. Table 6 summarizes estimates for the years 2010, 2030, and 2050. Global fuel consumption is shown to be $3.0-4.0 \mathrm{Gt}$ and $2.8-4.7 \mathrm{Gt}$, or $128-171 \mathrm{EJ}$ and 122-203 EJ, across the four IPCC scenarios (A1B, A2, B1, and B2) in the years 2030 and 2050, respectively. The corresponding 2030 and 2050 emissions for the four scenarios are 101-138 Tg and 95-168 $\mathrm{Tg}$ for $\mathrm{CO}, 44-54 \mathrm{Tg}$ and $46-65 \mathrm{Tg}$ for $\mathrm{NO}_{\mathrm{x}}, 14-18 \mathrm{Tg}$ and $14-23 \mathrm{Tg}$ for $\mathrm{THC}$, and 3.6-4.4 Tg and 3.5-4.9 Tg for PM, respectively.

Despite the increasing global fuel use, especially under scenarios $\mathrm{A} 1 \mathrm{~B}$ and $\mathrm{A} 2$, emissions under all scenarios decrease in the next one or two decades before starting to increase again. The major reason for the decrease in near-term emissions is the implementation of stringent emission standards, particularly for on-road vehicles (Yan et al., 2011), which contribute more than $60 \%$ of the total fuel use. The increase in emissions after about 2030 can be explained by the following reasons. First, there is a significant growth in on-road vehicle emissions in Africa, which is projected to experience rapid growth in the number of vehicles having no or lax emission controls (Yan et al., 2011). Second, CO and THC emissions are constantly increasing from non-road engines, because emission control of non-road gasoline engines is not as stringent as for on-road and there is greater use of non-road gasoline engines. Tables S9 and S10 in the Supplement provide regional emission intensities of $\mathrm{CO}$ and THC for non-road engines. While regional emission intensity for gasoline and/or diesel engines decreases with time, overall emission intensity, which largely depends on the ratio between gasoline and diesel, may not decrease. The effects of 
Table 6. Fuel consumption (unit: $\mathrm{Pg}_{\mathrm{gear}}{ }^{-1}$ ) and emissions (unit: $\mathrm{Tg}_{\mathrm{year}}{ }^{-1}$ ) from different transport modes in year 2010,2030 , and 2050.

\begin{tabular}{|c|c|c|c|c|c|c|c|c|c|c|}
\hline \multirow[t]{2}{*}{ Variable } & \multirow[t]{2}{*}{ Mode } & \multirow[t]{2}{*}{2010} & \multicolumn{4}{|c|}{2030} & \multicolumn{4}{|c|}{2050} \\
\hline & & & A1B & $\mathrm{A} 2$ & B1 & B2 & A1B & A2 & B1 & B2 \\
\hline \multirow[t]{7}{*}{ Fuel $^{\mathrm{a}}$} & On-road ${ }^{b}$ & 1.7 & 2.71 & 2.05 & 2.1 & 1.86 & 2.84 & 2.38 & 1.93 & 1.53 \\
\hline & Non-road & 0.25 & 0.35 & 0.28 & 0.29 & 0.31 & 0.37 & 0.27 & 0.25 & 0.26 \\
\hline & Shipping & 0.25 & 0.37 & 0.33 & 0.36 & 0.35 & 0.55 & 0.42 & 0.49 & 0.46 \\
\hline & Aviation & 0.24 & 0.44 & 0.38 & 0.36 & 0.37 & 0.77 & 0.47 & 0.43 & 0.44 \\
\hline & Rail & 0.03 & 0.09 & 0.06 & 0.08 & 0.07 & 0.17 & 0.09 & 0.14 & 0.13 \\
\hline & Total & 2.47 & 3.97 & 3.1 & 3.19 & 2.96 & 4.69 & 3.62 & 3.23 & 2.82 \\
\hline & Total $\left(\text { EJ year }^{-1}\right)^{\mathrm{c}}$ & 107 & 171 & 134 & 138 & 128 & 203 & 157 & 139 & 122 \\
\hline \multirow[t]{6}{*}{$\mathrm{CO}$} & On-road ${ }^{b}$ & 97.4 & 72.8 & 53.8 & 58.8 & 51.2 & 93 & 63.2 & 65.1 & 45.3 \\
\hline & Non-road & 35.9 & 59.9 & 43.2 & 49 & 48.8 & 69.1 & 45.4 & 46.4 & 44.9 \\
\hline & Shipping & 1.19 & 1.77 & 1.57 & 1.69 & 1.64 & 2.59 & 1.96 & 2.31 & 2.17 \\
\hline & Aviation & 1.92 & 2.33 & 1.98 & 1.92 & 1.93 & 2.64 & 1.61 & 1.47 & 1.5 \\
\hline & Rail & 0.35 & 0.84 & 0.56 & 0.73 & 0.73 & 1.08 & 0.57 & 0.89 & 0.79 \\
\hline & Total & 137 & 138 & 101 & 112 & 104 & 168 & 113 & 116 & 95 \\
\hline \multirow[t]{6}{*}{$\mathrm{NO}_{\mathrm{x}}$} & On-road ${ }^{b}$ & 25.2 & 18.1 & 13.7 & 14.7 & 13.3 & 21.9 & 14.9 & 15.3 & 11.1 \\
\hline & Non-road & 10.1 & 6.58 & 5.7 & 5.87 & 5.87 & 3.84 & 2.9 & 2.86 & 2.91 \\
\hline & Shipping & 16.2 & 20.4 & 18.1 & 19.4 & 18.9 & 27.3 & 20.7 & 24.3 & 22.8 \\
\hline & Aviation & 3.02 & 4.95 & 4.42 & 3.85 & 4.14 & 7.5 & 5.4 & 3.4 & 4.4 \\
\hline & Rail & 1.59 & 3.48 & 2.32 & 3.05 & 3.04 & 4.52 & 2.33 & 3.65 & 3.33 \\
\hline & Total & 56.1 & 53.5 & 44.2 & 46.9 & 45.2 & 65.1 & 46.2 & 49.5 & 44.5 \\
\hline \multirow[t]{6}{*}{ THC } & On-road $^{b}$ & 12.1 & 8.77 & 6.52 & 7.09 & 6.3 & 11.4 & 7.66 & 7.96 & 5.65 \\
\hline & Non-road & 4.87 & 6.7 & 4.85 & 5.57 & 5.56 & 8.11 & 5.19 & 5.48 & 5.36 \\
\hline & Shipping & 1.26 & 1.8 & 1.6 & 1.72 & 1.68 & 2.56 & 1.94 & 2.28 & 2.14 \\
\hline & Aviation & 0.3 & 0.29 & 0.24 & 0.24 & 0.24 & 0.25 & 0.16 & 0.14 & 0.14 \\
\hline & Rail & 0.25 & 0.64 & 0.43 & 0.56 & 0.56 & 0.73 & 0.39 & 0.6 & 0.54 \\
\hline & Total & 18.8 & 18.2 & 13.6 & 15.2 & 14.3 & 23.1 & 15.3 & 16.5 & 13.8 \\
\hline \multirow[t]{6}{*}{ PM } & On-road $^{b}$ & 1.49 & 1.05 & 0.83 & 0.88 & 0.8 & 1.26 & 0.82 & 0.89 & 0.62 \\
\hline & Non-road & 1.28 & 0.99 & 0.83 & 0.87 & 0.87 & 0.75 & 0.51 & 0.53 & 0.52 \\
\hline & Shipping & 1.38 & 1.96 & 1.74 & 1.87 & 1.82 & 2.77 & 2.1 & 2.47 & 2.32 \\
\hline & Aviation & 0.006 & 0.011 & 0.009 & 0.009 & 0.009 & 0.019 & 0.012 & 0.011 & 0.011 \\
\hline & Rail & 0.21 & 0.35 & 0.23 & 0.3 & 0.31 & 0.15 & 0.08 & 0.13 & 0.1 \\
\hline & Total & 4.37 & 4.36 & 3.62 & 3.93 & 3.8 & 4.94 & 3.53 & 4.02 & 3.58 \\
\hline
\end{tabular}

\footnotetext{
${ }^{a}$ Fuel for on- and non-road, shipping, and aviation is oil; that for rail is oil and coal.

${ }^{b}$ For on-road vehicles, the historical fuel use from IEA is until 2005, in order to make the results consistent with Yan et al. (2011). The values shown here are from the A1B scenario.

${ }^{c}$ The net calorific values of gasoline, diesel, and coal used in this paper are $44.0 \mathrm{MJ} \mathrm{kg}^{-1}, 42.6 \mathrm{MJ} \mathrm{kg}^{-1}$, and $21.2 \mathrm{MJ} \mathrm{kg}{ }^{-1}$, respectively.
}

increasing gasoline consumption could overcome the effects of emission reduction by implementation of emission standards. Finally, shipping makes a greater contribution to total $\mathrm{NO}_{\mathrm{x}}$ and $\mathrm{PM}$ emissions.

$\mathrm{CO}$ and THC emissions are dominated by emissions from on-road vehicles at the beginning of the period (Fig. 2, middle panel). Of all the $\mathrm{CO}$ and THC emissions from on-road vehicles, LDGVs contribute over $80 \%$ (as shown in Fig. S4 in the Supplement). However, emissions from non-road engines have the potential to become the leading contributor as time goes on. Though on-road vehicles consume about seven times as much fuel as non-road engines, their net $\mathrm{CO}$ and THC emissions become comparable, especially after 2030 . This is because on-road vehicles have been required to use increasingly advanced emission control technologies in order to comply with more stringent emission standards. Nevertheless, on-road vehicles and shipping govern the emission trends of $\mathrm{NO}_{\mathrm{x}}$ and $\mathrm{PM}$, and they contribute $66-83 \%$ of the total. Though HDDVs consume less than half of the total onroad fuel, they dominate emissions of $\mathrm{NO}_{\mathrm{x}}$ and $\mathrm{PM}$ from onroad vehicles and contribute $60-80 \%$ and $80-90 \%$ of the total, respectively (Fig. S4 in the Supplement). The constant increase of $\mathrm{NO}_{\mathrm{x}}$ and $\mathrm{PM}$ emissions from shipping makes it play a more significant role in future years; this can be explained by the growth in the world economy, which necessitates the movement of an increasing amount of goods by sea, and the absence of further tightening of emission regulations for ships. 

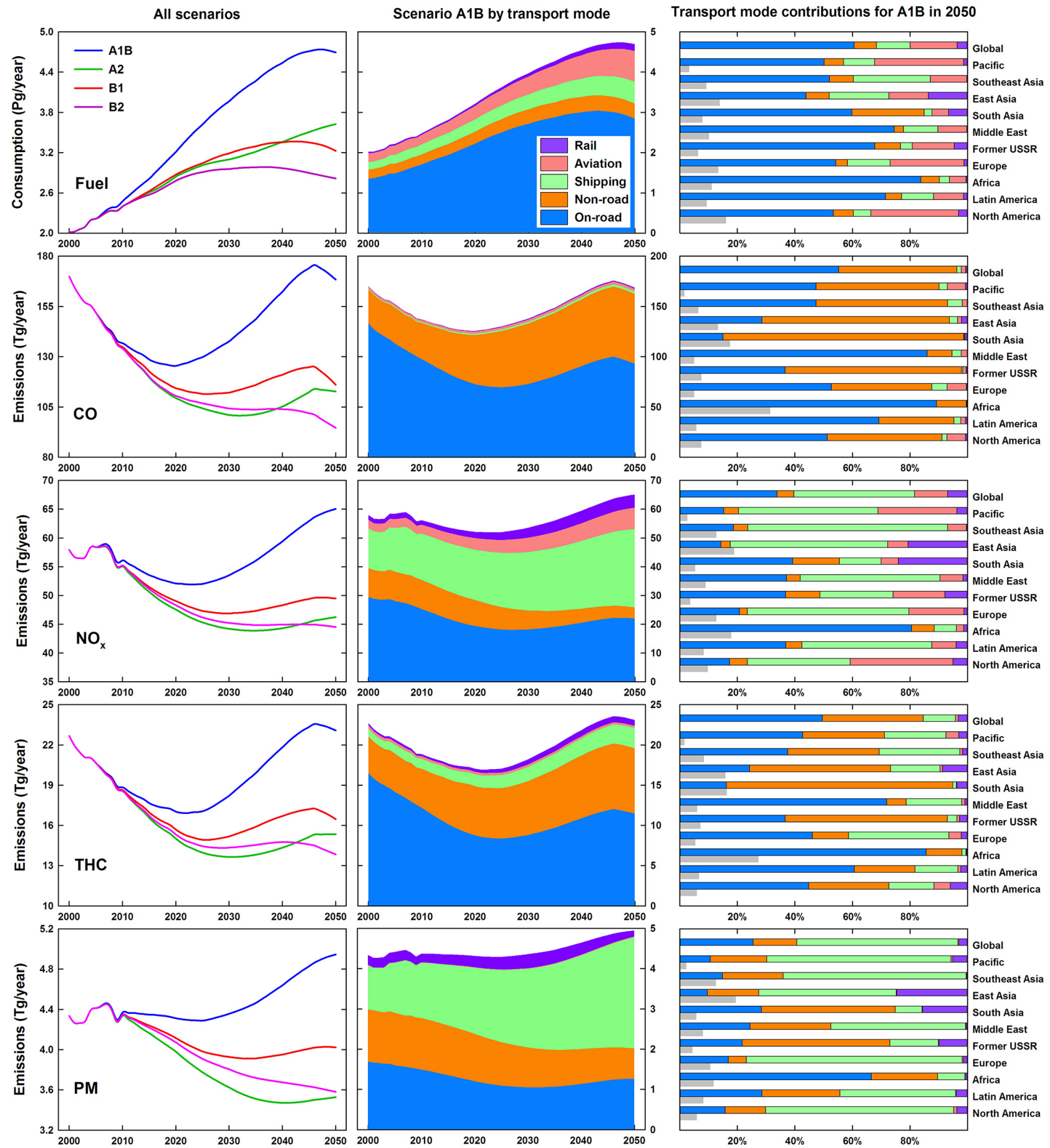

Figure 2. Estimated global fuel consumption and emissions of $\mathrm{CO}, \mathrm{NO}_{\mathrm{x}}, \mathrm{THC}$, and $\mathrm{PM}$ from the transportation sector under all scenarios (A1B, A2, B1, and B2) (left) by transport mode under scenario A1B (middle), and by transport mode fractional contribution in different regions under scenario A1B in year 2050 (right). The gray bars in the right panel represent regional contributions to the global emissions.

\subsection{Regional emissions}

The right-hand-side panel of Fig. 2 presents the fractions of each transportation mode in 10 regrouped world regions (Table S1 in the Supplement), as well as regional contributions to the global emissions. We show fractions of fuel consumption and the emissions of the four species in the year 2050 under the A1B scenario. Regional estimates in other years and other scenarios are shown in Fig. S5 and Tables S11-S14 
in the Supplement. Table S17 in the Supplement shows fuel consumption by region and transportation mode.

As shown in Fig. 2, Table S11, and Fig. S5 in the Supplement, there is a significant shift in the regional distribution of $\mathrm{CO}$ emissions, with an increasing proportion of emissions coming from Africa and South Asia. Up to 2010, emissions are dominated by Latin America and East Asia, which together account for $34 \%$ of total CO emissions (Fig. S5 in the Supplement). After 2010, emissions from Africa and South Asia increase more rapidly than those from other regions and contribute 31 and $17 \%$, respectively, of global CO emissions by the year 2050 (Fig. S5 in the Supplement). THC emissions show similar changes in regional contributions, but the $\mathrm{NO}_{\mathrm{x}}$ and $\mathrm{PM}$ emission contributions do not alter much.

The regional composition of future emissions by transportation mode varies with species and year. Non-road engines are the dominant contributor to $\mathrm{CO}$ emissions in many regions by the year 2050, particularly Asia (those in South Asia, East Asia, and Southeast Asia together account for $70 \%)$ and the former USSR (61\%). On-road vehicles and non-road engines contribute approximately equally in North America (51 and 40\%), Europe (53 and 35\%), and the Pacific (47 and $43 \%$ ). In the Middle East (86\%), Africa (89\%), and Latin America (69\%), emissions from on-road vehicles continue to contribute large shares of total emissions because of the combined effects of a large fraction of fuel use and lax emission standards. The sources of THC are somewhat similar to $\mathrm{CO}$, except that shipping has more influence in some regions, particularly Europe (35\%), Southeast Asia (25\%), and the Pacific (21\%). Shipping drives $\mathrm{NO}_{\mathrm{x}}$ and PM emissions in most regions by the year 2050. In Africa there is a large contribution (over $70 \%$ ) from on-road vehicles to all pollutants, due to the delayed introduction of advanced emission standards.

\subsection{Comparison with other studies}

\subsubsection{Global emissions}

Other estimates of future emissions of $\mathrm{CO}, \mathrm{NO}_{\mathrm{x}}, \mathrm{THC}$, and $\mathrm{PM}$, for the purposes of studying future air quality and climate change, have used global emission projection approaches such as GAINS (Klimont et al., 2009), IEA/SMP (Fulton and Eads, 2004), QUANTIFY (DLR, 2009), and the new IPCC AR5 Representative Concentration Pathways (RCP) database (Moss et al., 2010). Historical and presentday global emissions, which are used as the baseline for future emissions, often rely on the EDGAR (Electronic Data Gathering, Analysis and Retrieval) database (JRC/PBL, 2011), RETRO (Schultz et al., 2007), or a combination of several existing emission databases (Lamarque et al., 2010; Zhang et al., 2012). In this section, we compare our results with emissions in the GAINS, IEA/SMP, and QUANTIFY models, none of which represent changes of multiple technology classes explicitly. These three models are chosen because they include both historical and future emissions, provide emissions and corresponding fuel use, specify onroad and non-road components of the transportation sector, and make consistent assumptions among regions. Additionally, historical emissions from EDGAR, UNFCCC (United Nations Framework Convention on Climate Change; UNFCCC, 2006), and EMEP (European Monitoring and Evaluation Programme; EMEP, 2013) data sets are compared to provide more insight.

Because on-road vehicles represent a significant contribution to total emissions, especially for $\mathrm{CO}$ and THC, we first compare our global on-road emission estimates with previous work in Fig. 3 (right panel). The other studies do not explicitly model the influence of superemitters, which may contribute over $50 \%$ of total emissions (Yan et al., 2011), so we add two extra scenarios that do not include any consideration of superemitters (dashed lines) for comparison purposes. Emissions of PM from on-road vehicles have already been compared with other studies in Yan et al. (2011), so they are not discussed here. The historical EDGAR emission estimates show a similar trend and magnitude for $\mathrm{NO}_{\mathrm{x}}$ emissions up to the year 2010; however, EDGAR estimates for $\mathrm{CO}$ and THC emissions are higher. Estimates from the GAINS model are generally within the bounds of our estimates across multiple scenarios, though they are slightly larger before 2010. The IEA/SMP model shows much higher emissions for $\mathrm{CO}$ and THC in the first 20 years of the forecast, because their model assumes that LDGVs and LDDVs have the same emission factors, while we use measured emission factors and differentiate them by not only fuel type but also emission standard and vehicle age. Since their model is more optimistic with regard to emission standard implementation, even in Africa, emission projections in the future are lower than our estimates even without consideration of superemitters after around 2025 .

For illustrative purposes, we compare our results with the latest RCP scenarios, though the approach taken to generate the RCPs is very different from the SRES process and a detailed comparison is problematic. "Rather than starting with detailed socioeconomic storylines to generate emissions and then climate scenarios", RCPs were developed by a parallel process that "begins with the identification of important characteristics for scenarios of radiative forcings for climate modelling" (Moss et al., 2010). RCPs are consistent sets of projections of the components of radiative forcing that are meant to serve as inputs for climate modeling, pattern scaling, and atmospheric chemistry modeling. A specific emission scenario for each RCP is identified from the peerreviewed literature as a plausible pathway towards reaching the target radiative forcing trajectory (Moss et al., 2010). Note that while the four SRES scenarios used in this work are all reference scenarios, three of the four RCPs are climate policy scenarios, which have the structure of transportation changed from reference case conditions to lower pollutant emissions (van Vuuren et al., 2011). 

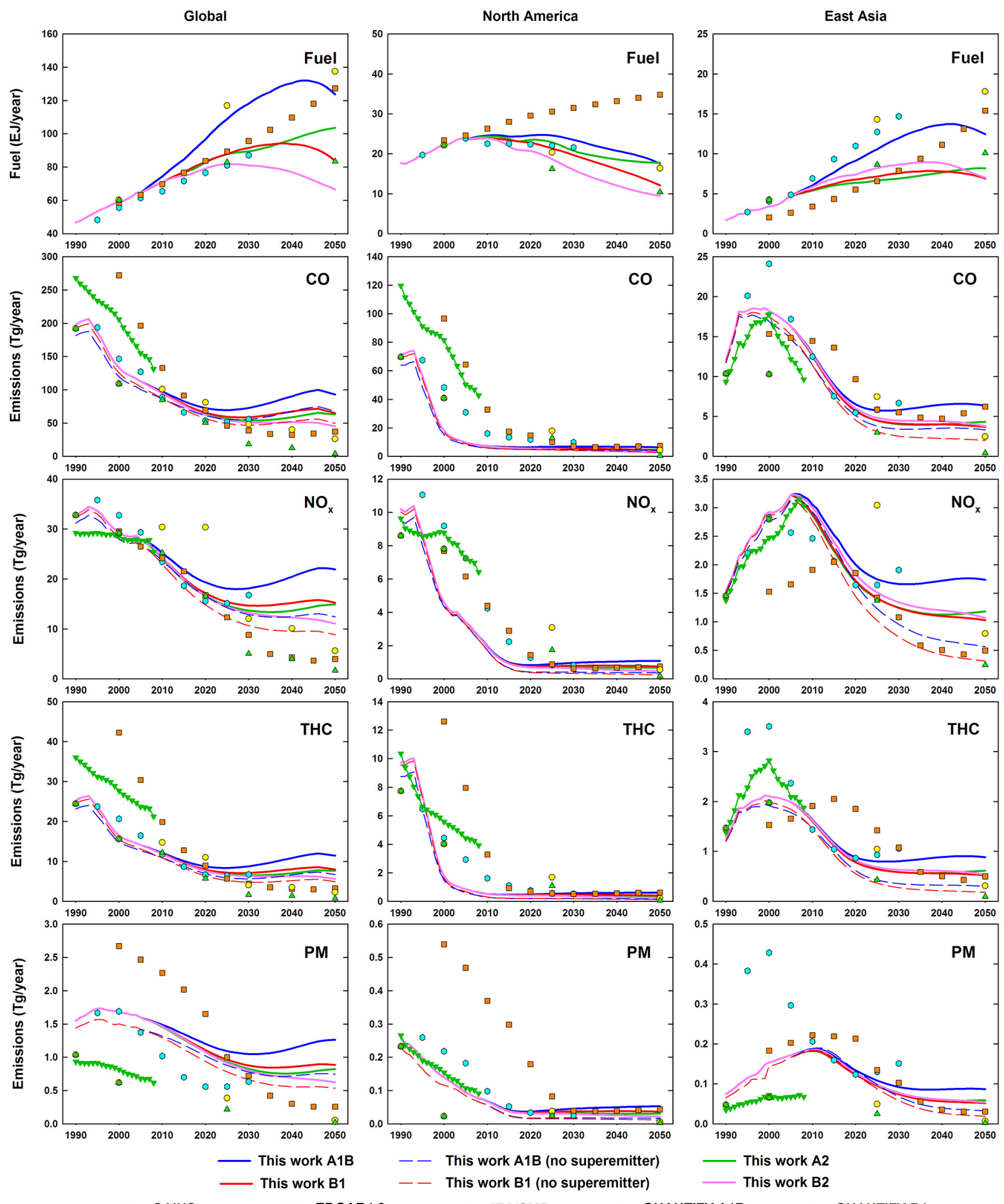

- GAINS

- IEA/SMP

QUANTIFY A1B

$\triangle \quad$ QUANTIFY B1

Figure 3. Comparison of global (left) and regional (North America, middle; East Asia, right) fuel and emission estimates for on-road vehicles in this work with previous studies: GAINS (scenario: BL_WEO_2010) (Klimont et al., 2009), EDGAR (version 4.2) (JRC/PBL, 2011), IEA/SMP (Fulton and Eads, 2004), and QUANTIFY (DLR, 2009). 
Figure 5 shows a comparison of global emission estimates for the transportation sector as a whole, including on-road vehicles, non-road engines, shipping, aviation, and rail. The annual global emissions estimated in this work have trends that are similar to other work up to 2010 but of somewhat different magnitude. In part due to the high growth of the shipping contribution, our estimates of $\mathrm{NO}_{\mathrm{x}}$ emissions under scenario A1B tend to exceed RCP8.5 after 2040, and PM emissions show comparable or even higher emissions than the RCPs. Between 2010 and 2030, emission projections of $\mathrm{CO}, \mathrm{NO}_{\mathrm{x}}$, and THC in this work are consistently lower than RCPs, especially for THC, but higher than QUANTIFY. If emissions from shipping are excluded from the total, our projections of PM emissions are also lower than the ranges of RCPs. Specific details about the RCP emission calculation process are not revealed in published documentation, and we do not have adequate information to make further exploration. The emission discrepancies between the RCP scenarios and this work may depend on how emission factors are assumed to change over time.

\subsubsection{Regional emissions}

This section presents a comparison of emission estimates of on-road vehicles from this work and various other studies for five key regions: North America, OECD Europe, Eastern Europe, East Asia, and South Asia, as shown in Figs. 3 and 4. These five regions are selected for the purpose because they play important roles in the determination of current and future emissions. Due to the fact that aviation and shipping are more international activities, they are not compared at the regional level. Regional comparisons of PM emissions from on-road vehicles were compared in Yan et al. (2011) and they will be not repeated in this paper.

In general, emission estimates for North America in this work are consistent with other studies in terms of emission trends, yet our estimates have lower magnitudes and a faster decline especially for CO and THC between 2000 and 2020. Emissions from the IEA/SMP model are overestimated, particularly before 2010, because of its emission factor choice (as explained in Sect. 4.3.1). Emissions from GAINS are higher than our estimates. Though fuel use in GAINS is closer to or even lower than our work, their net emission factor or emission intensity is significantly higher because of the slower phase-in of advanced emission standards and the use of emission factors for European emission standards. For example, while the GAINS model shows that LDGVs under the Euro II standard still contribute over $50 \%$ of fuel consumption in 2010, the dominant LDGVs in our model are vehicles under the Tier 2-2007 standard. The GAINS results reflect slower retirement rates and more old vehicles in the fleet.

Emission estimates for East Asia show wide variation. EDGAR represents a good match with our study for past emissions of $\mathrm{CO}$ and $\mathrm{NO}_{\mathrm{x}}$, while their emissions are higher for THC and lower for PM. This close match is partly due to use of the same IEA fuel data. The GAINS model tends to have higher emission estimates for $\mathrm{CO}$, THC, and PM before the year 2000 due to greater shares of vehicles without emission standards. Emission projections between the years 2010 and 2030 in this work show a continuous decrease in East Asia, unlike in the GAINS model where emissions increase after 2020. Such an increase is caused by their higher estimates of the growth rate of vehicle activity and slower adoption of Euro VI emission standards. Emission projections after 2020 from the IEA/SMP model and QUANTIFY lie within the range of the scenarios from this work, and their emissions are approaching or lower than those from the scenarios without superemitters in 2050. This highlights the importance of separating superemitters from other emitters so that future emissions are not underestimated. It also indicates that the potential environmental issues caused by superemitters must be addressed specifically by policy makers, because such vehicles make a highly significant contribution to total emissions.

Total emissions from on-road vehicles for OECD Europe are compared in the left panel of Fig. 4. All the inventories show emissions decreasing continuously in OECD Europe, despite increasing fuel consumption until the 2020 s. Small differences from EDGAR, GAINS, QUANTIFY, UNFCCC, and EMEP are observed in $\mathrm{NO}_{\mathrm{x}}$ and $\mathrm{PM}$ emission estimates, within a range from -14 to $+18 \%$. For $\mathrm{CO}$ and THC, this work shows generally lower emission estimates than the other studies. Though the IEA/SMP model has similar fuel estimates to the IEA database before 2010, emissions are 0.5-5 times higher than ours (except for $\mathrm{NO}_{\mathrm{x}}$ emissions). The IEA/SMP model, which projects fuel use to be similar to the A2 scenario, has better agreement with this work on the emission projections for four pollutants after 2020.

The middle and right-hand-side panels of Fig. 4 show emission comparisons in Eastern Europe and South Asia. Emissions for these two regions have larger differences from the other studies, especially South Asia. For Eastern Europe, while UNFCCC presents generally lower emission estimates than this work, the IEA/SMP model provides higher emissions except for $\mathrm{NO}_{\mathrm{x}}$; emissions for $\mathrm{CO}, \mathrm{NO}_{\mathrm{x}}$, and $\mathrm{THC}$ from GAINS, QUANTIFY, and EMEP are relatively closer to this work, but $80 \%$ maximal differences are observed. Emission estimates for South Asia from different studies are most divergent among the regions that are compared in this paper. The GAINS model even shows increasing emissions after 2015, while the other studies show emissions decreasing until at least 2030. This diversity of forecasts implies a large uncertainty of emission factors and the composition of the vehicle fleet in South Asia. Further investigations are required in order to have a better understanding of current and future emissions in regions with inadequate information. 

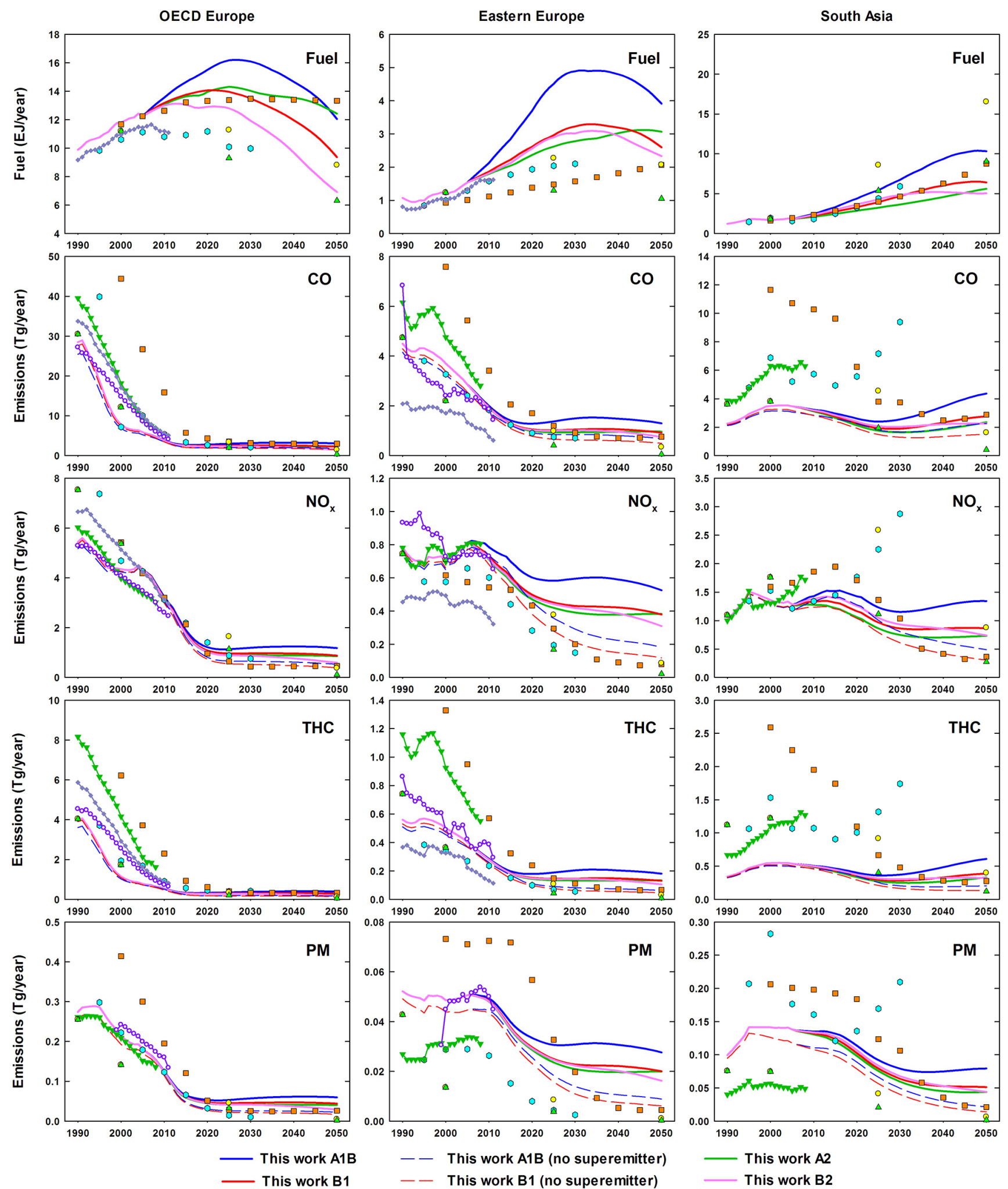

- GAINS $\longrightarrow$ EDGAR4.2

- This work B1 (no superemitter)

This work B2

Figure 4. Comparison of regional (OECD Europe, left; Eastern Europe, middle; South Asia, right) fuel and emission estimates for on-road vehicles in this work with previous studies: GAINS (scenario: BL_WEO_2010) (Klimont et al., 2009), EDGAR (version 4.2) (JRC/PBL, 2011), IEA/SMP (Fulton and Eads, 2004), QUANTIFY (DLR, 2009), UNFCCC (UNFCCC, 2006), and EMEP (EMEP, 2013). 

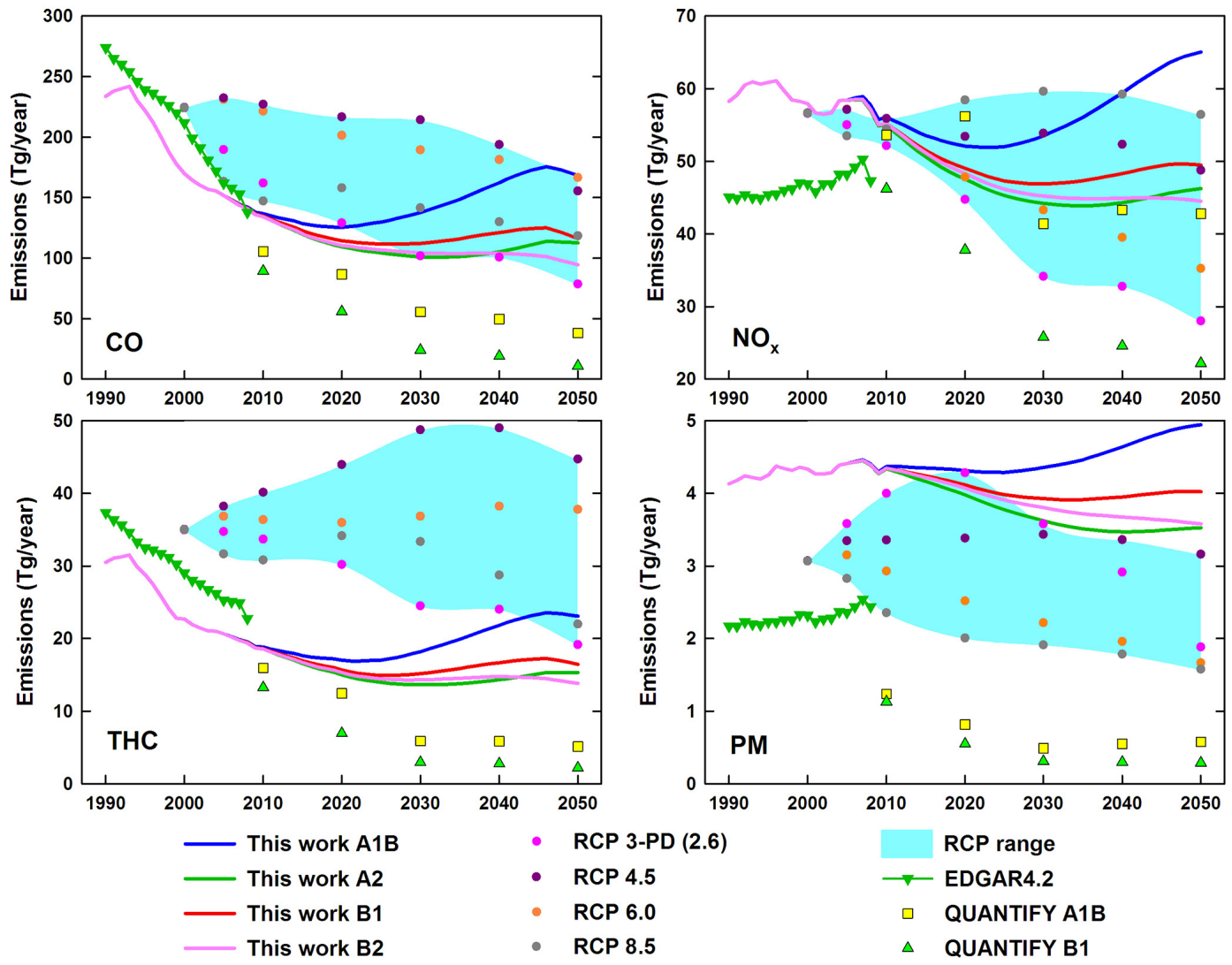

Figure 5. Comparison of global emission estimates for the whole transportation sector. The solid lines are total emissions estimated in this work under scenarios A1B, A2, B1, and B2, including on-road vehicles, non-road engines, total shipping (domestic and international), total aviation (domestic and international), and rail. The RCP scenarios (Moss et al., 2010) include emissions from surface transportation, aviation, and international shipping. EDGAR (JRC/PBL, 2011) includes emissions from road transport, inland navigation, international shipping, domestic and international aviation, and rail. QUANTIFY (DLR, 2009) includes emissions from road, maritime shipping, inland navigation, aviation, and rail. For PM, this work shows emissions of total PM, EDGAR shows emissions of PM 10 , QUANTIFY and RCP show the sum of the emissions of BC and OC.

\section{Conclusions and recommendations}

\subsection{Conclusions}

This paper presents projections of exhaust emissions of $\mathrm{CO}$, $\mathrm{NO}_{\mathrm{x}}$, THC, and PM from the transportation sector, consisting of on-road vehicles, non-road engines, shipping, aviation, and rail. It presents emissions from 2010 to 2050 annually under four IPCC scenarios. Future emissions from onroad vehicles and non-road engines are estimated within the framework of the SPEW-Trend model, incorporating explicit representation of the dependence of technology choice on socioeconomics and other variables. For completeness, emissions from shipping, aviation, and rail are compiled from other related studies. Our emission trends and magnitudes are somewhat different from previous work, the most important reason for which is that we account for the explicit dynamic relationship between socioeconomic factors and technological change, and other studies do not.
At the global level, on-road vehicles and non-road engines dominate global $\mathrm{CO}$ and THC emissions, while on-road vehicles and shipping contribute most to $\mathrm{NO}_{\mathrm{x}}$ and $\mathrm{PM}$ emissions. In general, the effects of tighter emission standards for onroad vehicles in many parts of the world offset the growth in fuel consumption during the first one or two decades of projections, and therefore the emissions of all pollutants decrease. As time goes on and particularly after 2030, however, emissions from on-road vehicles in Africa and emissions from non-road engines and shipping comprise an everincreasing share of total emissions and lead to an increase in emissions in some scenarios. The growing importance of non-road engines and shipping may result in larger uncertainties for total future emissions. The regulation of non-road engines and shipping is relatively recent, as compared to onroad vehicles, and there is less historical precedent available to guide projections. Further, activity levels and emission factors for these source types are more uncertain. 
At the regional level, emissions from Latin America and East Asia contribute most to global CO and THC emissions in the year 2010; this dominance shifts to Africa and South Asia in the future. By the year 2050, of the CO emissions, non-road engines contribute the greatest fraction in Asia and the former USSR, while on-road vehicles make the greatest contribution in Latin America, Africa, and the Middle East. For $\mathrm{NO}_{\mathrm{x}}$ and $\mathrm{PM}$ emissions, shipping controls the trend in most regions.

One of the major goals of this work is to build a new data set of potential future emissions to support climate modeling. In previous studies (Berntsen and Fuglestvedt, 2008; Unger et al., 2010), present-day or historical emissions have often been used to drive climate models, because regional and global projections of the emissions of appropriate species were not available. Some studies simply extrapolated current emissions into the future with linear assumptions about the relationship between emissions and economic growth. These methods are not satisfactory because they neglect the fact that emission factors are strongly dependent on in-use technology and applicable regulatory standards, both of which vary dramatically around the world today and will undergo transitions at different rates in the future. These factors that govern technology change will dramatically influence the trajectory of future emissions. Our dynamic technology model can also help to identify the major emission contributors by technology type, transport mode, and world region, and thereby allow policymakers to design more efficient and effective emission control policies.

Overall, this paper presents robust and plausible future emissions with the application of a dynamic technology model following a specific set of assumptions for vehicle retirement, implementation of emission standards, emission degradation, and superemitter development. For the first time, quantitative relationships are used to project how the technology mix in the transportation sector will change under different socioeconomic conditions. Some caveats are necessary, however. Vehicle retirement and emission degradation are constrained by a limited set of observations and measurements. These loose constraints introduce uncertainties in the emission projections, which may be improved by the acquisition of more observational and test data, especially for developing countries. Timing of the introduction of emission standards in different regions is based on assumptions that consider effects such as trends in neighboring countries or emerging air quality problems, in addition to income; however, circumstances controlling the implementation of emission standards could alter and result in a change in future emissions. We also assume that the effectiveness of emission standards is the same across regions and that no further emission standards emerge beyond the cleanest ones presently in place. The former assumption may underestimate emissions and the latter one may slightly overestimate emissions in the future. Finally, our representation of superemitters is derived from very limited information about the causes and preva- lence of vehicles with very high emission factors. Because of the importance of superemitters in determining emission trends, a better understanding of such vehicles is urgently needed.

\subsection{Recommendations for future research}

\subsubsection{Updates of scenarios}

It is important that the socioeconomic drivers and fuel use are periodically updated when new scenarios are developed. This work is based on four IPCC scenarios, which were developed for the SRES (Nakicenovic et al., 2000). These four scenarios were used in the third (TAR) and fourth (AR4) IPCC assessments of climate change and have been widely applied by other groups for global projections of greenhouse gases, but they are now outdated. Although we have updated the SRES scenarios with actual data from IEA for fuel use and the World Bank for GDP and population, these variables after the year 2010 (or 2005 for on-road vehicles) still follow the trends that were originally formulated in the IMAGE model. These trends therefore do not reflect factors that will have influenced socioeconomic development within the past decade or two. There is already an effort underway to produce updated socioeconomic pathways, called shared socioeconomic pathways (SSPs) (Kriegler et al., 2012; van Vuuren et al., 2012). When the SSPs are completed and available, it will be possible to compare the emission results with those driven by SRES scenarios. In principle, SPEW-Trend can be driven by the forecasts of any macroeconomic model, but those forecasts need to provide the basic socioeconomic parameters that govern emissions. In order to generate climate and air pollution projections that are both consistent and widely used, greater integration among technology-rich models such as SPEW-Trend, scenario-defining macroeconomic models, and climate pathway models needs to be developed.

\subsubsection{Dynamic technological changes in shipping, aviation, and rail}

Unlike emissions from on-road vehicles and non-road engines, the emissions from shipping, aviation, and rail in this work are based on fuel consumption and emission factors gathered from other studies. These studies have considered technology development and fleet turnover to some extent, yet these changes are not dynamic. In some cases, they are simply based on expert judgment. The methodology used here for on-road vehicles and non-road engines is readily transferable to other source types having the necessary supporting information, and it is recommended that our approach be adapted in future work to shipping, aviation, and rail. In order to represent dynamic changes in these three modes, and make them consistent with on-road vehicles and non-road engines, we need to begin to gather information 
about the factors that drive technology preference and retirement decision-making for ships, aircraft, and locomotives.

\subsubsection{Uncertainty analysis}

It is not possible to apply the traditional approaches to characterizing uncertainties for estimates of future emissions. We clearly cannot measure the emission rates of 2050 vehicles in the laboratory, and we have no way of knowing the relative likelihood of particular future pathways of human development. For this reason, few studies of future emissions have even addressed the question of uncertainty. Nakicenovic et al. (2000) recommended the scenario approach to describe the range of possible future emissions developed by complex systems that are "either inherently unpredictable, or that have high scientific uncertainties". Some estimates of historical and present-day emissions (Bond et al., 2004; Lu et al., 2011; Smith et al., 2011; Zhao et al., 2011) have coupled uncertainties in activity rates, fuel use, and emission characteristics to give some indication of the uncertainty in the final emission estimate. However, in addition to the uncertainty in these factors, the relationships that link socioeconomic factors and technological change to determine future technology shares and the timing of technology and regulatory transitions are other significant sources of uncertainty in this type of work. Many of the relationships involved in the SPEW-Trend model, such as retirement rates, degradation rates, and superemitter transition rates, are only loosely constrained by observations. Yan et al. (2014) demonstrated how uncertainties in model input parameters affect projected emissions from on-road vehicles and found that the emission uncertainty caused by lack of knowledge about technology composition is about the same as the uncertainty contributed by alternative economic scenarios. The results presented in this paper must be understood in the context of these uncertainties.

\section{The Supplement related to this article is available online at doi:10.5194/acp-14-5709-2014-supplement.}

Acknowledgements. This work is supported by the US Department of Agriculture, National Institute of Food and Agriculture, through the award number 2012-67003-30192 to the University of Chicago and by the National Science Foundation EaSM program, through the award number AGS-1049200 at NCSU. We are grateful for the support of the USDA Project Officer, L. M. Tupas, and the NSF Program Director, A. S. Bamzai. Argonne National Laboratory is operated by UChicago Argonne, LLC under Contract no. DE-AC02-06CH11357 with the US Department of Energy.

Edited by: P. Chuang

\section{References}

Arora, S., Vyas, A., and Johnson, L. R.: Projections of highway vehicle population, energy demand, and $\mathrm{CO}_{2}$ emissions in India to 2040, Nat. Resour. Forum, 35, 49-62, 2011.

Balkanski, Y., Myhre, G., Gauss, M., Rädel, G., Highwood, E. J., and Shine, K. P.: Direct radiative effect of aerosols emitted by transport: from road, shipping and aviation, Atmos. Chem. Phys., 10, 4477-4489, doi:10.5194/acp-10-4477-2010, 2010.

Ban-Weiss, G. A., Lunden, M. M., Kirchstetter, T. W., and Harley, R. A.: Measurement of black carbon and particle number emission factors from individual heavy-duty trucks, Environ. Sci. Technol., 43, 1419-1424, 2009.

Baughcum, S. L., Begin, J. J., Franco, F., Greene, D. L., Lee, D. S., McLaren, M.-L., Mortlock, A. K., Newton, P. J., Schmitt, A., Sutkus, D. J., Vedantham, A., and Wuebbles, D. J.: Aircraft Emissions?: Current Inventories and Future Scenarios, Chapter 9 of "Aviation and the Global Atmosphere", edited by: Penner, J. E., Lister, D. H., Griggs, D. J., Dokken, D. J., and McFarland, M., Special Report of the Intergovernmental Panel on Climate Change, Cambridge University Press, Cambridge, 1999.

Bek, B. H. and Sorenson, S. C.: Future emissions from railway traffic report for the project MEET?: Methodologies for estimating air pollutant emissions from transport, ET-EO-98-02, Technical University of Denmark, Lyngby, Denmark, 1998.

Berghof, R., Schmitt, A., Eyers, C., Haag, K., Middel, J., Hepting, M., Grübler, A., and Hancox, R.: CONSAVE 2050 final technical report: Constrained scenarios on aviation and emissions, German Aerospace Center (DLR), Germany, 2005.

Bergin, M. S., Harrell, M., and Janssen, M.: Locomotive emission inventories for the United States from ERTAC Rail, 2012 Annual International Emission Inventory Conference, Tampa, Florida, 13-16 August, 2012.

Berntsen, T. and Fuglestvedt, J.: Global temperature responses to current emissions from the transport sectors, P. Natl. Acad. Sci. USA, 105, 19154-19159, 2008.

Bishop, G. A. and Stedman, D. H.: A decade of on-road emissions measurements, Environ. Sci. Technol., 42, 1651-1656, 2008

Bluett, J., Dey, K., and Fisher, G.: Assessing vehicle air pollution emissions, NIWA Client Report: CHC2008-001, National Institute of Water \& Atmospheric Research Ltd, Christchurch, New Zealand, 2008.

Bond, T. C., Streets, D. G., Yarber, K. F., Nelson, S. M., Woo, J., and Klimont, Z.: A technology-based global inventory of black and organic carbon emissions from combustion, J. Geophys. Res., 109, D14203, doi:10.1029/2003JD003697, 2004.

Bond, T. C., Bhardwaj, E., Dong, R., Jogani, R., Jung, S., Roden, C., Streets, D. G., and Trautmann, N. M.: Historical emissions of black and organic carbon aerosol from energy-related combustion, 1850-2000, Global Biogeochem. Cy., 21, GB2018, doi:10.1029/2006GB002840, 2007.

Borken, J., Steller, H., Merétei, T., and Vanhove, F.: Global and country inventory of road passenger and freight transportation: Fuel consumption and emissions of air pollutants in year 2000, Transport. Res. Rec., 2011, 127-136, 2007.

Borken-Kleefeld, J., Kupiainen, K., Chen, Y., Hausberger, S., Rexeis, M., Sjodin, A., Jerksjo, M., and Tate, J: Remote sensing for identifying high emitters and validating emission models, ERMES 2012 Plenary Meeting, Brussels, Belgium, 2012. 
Buhaug, Ø., Corbett, J. J., Endresen, Ø., Eyring, V., Faber, J., Hanayama, S., Lee, D. S., Lee, D., Lindstad, H., Markowska, A. Z., Mjelde, A., Nelissen, D., Nilsen, J., Pålsson, C., Winebrake, J. J., Wu, W., and Yoshida, K.: Second IMO GHG study 2009, International Maritime Organization (IMO), London, UK, 2009.

Cadle, S. H., Mulawa, P. A., Hunsanger, E. C., Nelson, K., Ragazzi, R. A., Barrett, R., Gallagher, G. L., Lawson, D. R., Knapp, K. T., and Snow, R.: Composition of light-duty motor vehicle exhaust particulate matter in the Denver, Colorado Area, Environ. Sci. Technol., 33, 2328-2339, 1999.

Cofala, J., Amann, M., Klimont, Z., Kupiainen, K., and HöglundIsaksson, L.: Scenarios of global anthropogenic emissions of air pollutants and methane until 2030, Atmos. Environ., 41, 84868499, 2007.

Cooke, W. F. and Wilson, J. J. N.: A global black carbon aerosol model, J. Geophys. Res., 101, 19395-19409, doi:10.1029/96JD00671, 1996.

Corbett, J. J. and Koehler, H. W.: Updated emissions from ocean shipping, J. Geophys. Res., 108, 4650, doi:10.1029/2003JD003751, 2003.

Corbett, J. J., Lack, D. A., Winebrake, J. J., Harder, S., Silberman, J. A., and Gold, M.: Arctic shipping emissions inventories and future scenarios, Atmos. Chem. Phys., 10, 9689-9704, doi:10.5194/acp-10-9689-2010, 2010.

Cox, D. R.: Regression models and life-tables, J. Roy. Stat. Soc. B, 34, 187-220, 1972.

Dargay, J., Gately, D., and Sommer, M.: Vehicle ownership and income growth, worldwide?: 1960-2030, Energy J., 28, 143-170, 2007.

Dentener, F., Keating, T., and Akimoto, H.: Hemispheric transport of air pollution 2010, Part A: ozone and particulate matter, in: Air Pollution Studies No. 17, New York and Geneva, 2010.

Dieselnet: Nonroad diesel engines, available at: www.dieselnet. com/standards/eu/nonroad.php, last access: January 2012.

Durbin, T. D., Smith, M. R., Norbeck, J. M., and Truex, T. J.: Population density, particulate emission characterization, and impact on the particulate inventory of smoking vehicles in the South Coast Air Quality Management District, J. Air Waste Manage., 49, 28-38, 1999.

Endresen, Ø., Sørgård, E., Behrens, H. L., Brett, P. O., and Isaksen, I. S. A.: A historical reconstruction of ships' fuel consumption and emissions, J. Geophys. Res., 112, D12301, doi:10.1029/2006JD007630, 2007.

European Commission: Service contract for the further development and application of the transport and environmental TREMOVE model Lot 1 (Improvement of the data set and model structure), available online at: http://www.tremove.org (last access: 16 May 2013), 2007.

European Environmental Agency (EEA): TERM 200328 EEA 31-Specific emissions of air pollutants, available at: http://www.eea.europa.eu/data-and-maps/indicators/ specific-emissions-of-air-pollutants/term2003_28_eea31_ specific_emissions_of_air_pollutantsfinal.pdf (last access: 16 May 2013), 2004.

European Environmental Agency (EEA): EMEP/EEA emission inventory guidebook 2009, updated May 2012, available at: http: //eea.europa.eu/emep-eea-guidebook (last access: 16 May 2013), 2012a.
European Environmental Agency (EEA): Greenhouse gas emission trends and projections in Europe 2012, available online at: http://www.eea.europa.eu/publications/ ghg-trends-and-projections-2012 (last access: 16 May 2013), 2012b.

European Monitoring and Evaluation Programme (EMEP): available online at: http://www.ceip.at/webdab-emission-database/ emissions-as-used-in-emep-models/, last access: December 2013.

Eyers, C. J., Norman, P., Middel, J., Plohr, M., Michot, S., Atkinson, K., and Christou, R. A.: AERO2k global aviation emissions inventories for 2002 and 2025, QINETIQ/04/01113, QinetiQ Ltd, Hampshire, UK, 2004.

Eyring, V., Köhler, H. W., van Aardenne, J., and Lauer, A.: Emissions from international shipping: 1 . The last 50 years, J. Geophys. Res., 110, D17305, doi:10.1029/2004JD005619, 2005 a.

Eyring, V., Köhler, H. W., Lauer, A., and Lemper, B.: Emissions from international shipping: 2. Impact of future technologies on scenarios until 2050, J. Geophys. Res., 110, D17306, doi:10.1029/2004JD005620, 2005b.

Eyring, V., Isaksen, I. S. A., Berntsen, T., Collins, W. J., Corbett, J. J., Endresen, O., Grainger, R. G., Moldanova, J., Schlager, H., and Stevenson, D. S.: Transport impacts on atmosphere and climate: Shipping, Atmos. Environ., 44, 4735-4771, 2010.

Fearnleys: Fearnleys review 2007: The tanker and bulk markets and fleets, Oslo, Norway, 2007.

Fuglestvedt, J., Berntsen, T., Myhre, G., Rypdal, K., and Skeie, R. B.: Climate forcing from the transport sectors, P. Natl. Acad. Sci. USA, 105, 454-458, 2008.

Fulton, L. and Eads, G.: IEA/SMP model documentation and reference case projection, available at: http://www.wbcsd.org/web/ publications/mobility/smp-model-document.pdf (last access: 16 May 2013), 2004.

German Aerospace Center (DLR): QUANTIFY emission inventories and scenarios, available at: http://www.pa.op.dlr.de/quantify/ emissions/ (last access: 16 May 2013), 2009.

Greenspan, A. and Cohen, D.: Motor vehicle stocks, scrappage, and sales, Rev. Econ. Stat., 81, 369-383, 1999.

Hansen, A. D. A. and Rosen, H.: Individual measurements of the emission factor of aerosol black carbon in automobile plumes, J. Air Waste Manage., 40, 1654-1657, 1990.

Henderson, S. C., Wickrama, U. K., Baughcum, S. L., Begin, J. J., Franco, F., Greene, D. L., Lee, D. S., McLaren, M. L., Mortlock, A. K., Newton, P. J., Schmitt, A., Sutkus, D. J., Wedantham, A., and Wuebbles, D. J.: Aircraft emissions: Current inventories and future scenarios, in Aviation and the Global Atmosphere, edited by: Penner, J. E., Lister, D. H., Griggs, D. J., Dokken, D. J., and McFarland, M., Intergovernmental Panel on Climate Change, Cambridge Univ. Press, New York, 1999.

ICAO/FESG: Steering group meeting report of FESG CAEP/8 traffic and fleet forecasts, CAEP-SG/2082-IP/02 21/08/08, Seattle, 22-26 September 2008.

International Energy Agency (IEA): Energy Statistics of NonOECD Countries, Organization of Economic, Paris, 2012a.

International Energy Agency (IEA): Energy Statistics of OECD Countries, Organization for Economic, Paris, 2012b.

International Maritime Organization (IMO): Revised MARPOL Annex VI: Regulations for the prevention of air pollution from 
ships and $\mathrm{NO}_{\mathrm{x}}$ technical code 2008, 2009 Edition, London, UK, 2009.

International Union of Railways (UIC): Rail diesel emissions facts and challenges, available at: http://www.uic.org/IMG/pdf/ 060912_Rail_Diesel_8aout_06.pdf (last access: 16 May 2013), 2006.

Joint Research Centre (JRC)/Netherlands Environmental Assessment Agency (PBL): Emission Database for Global Atmospheric Research (EDGAR), release version 4.2., available at: http:// edgar.jrc.ec.europa.eu (last access: 16 May 2013), 2011.

Kim, B. Y., Fleming, G. G., Lee, J. J., Waitz, I. A., Clarke, J.-P., Balasubramanian, S., Malwitz, A., Klima, K., Locke, M., Holsclaw, C. A., Maurice, L. Q., and Gupta, M. L.: System for assessing aviation's global emissions (SAGE), Part 1: Model description and inventory results, Transport. Res. D-Tr. E., 12, 325-346, 2007.

Klimont, Z., Cofala, J., Bertok, I., Amann, M., Heyes, C., and Gyarfas, F.: Modelling particulate emissions in Europe: A framework to estimate reduction potential and control costs, IIASA interim report IR-02-076, Laxenburg, Austria, 2002.

Klimont, Z., Cofala, J., Xing, J., Wei, W., Zhang, C., Wang, S., Kejun, J., Bhandari, P., Mathur, R., Purohit, P., Rafaj, P., Chambers, A., Amann, M., and Hao, J.: Projections of $\mathrm{SO}_{2}, \mathrm{NO}_{\mathrm{x}}$ and carbonaceous aerosols emissions in Asia, Tellus B, 61, 602-617, 2009

Koffi, B., Szopa, S., Cozic, A., Hauglustaine, D., and van Velthoven, P.: Present and future impact of aircraft, road traffic and shipping emissions on global tropospheric ozone, Atmos. Chem. Phys., 10, 11681-11705, doi:10.5194/acp-10-11681-2010, 2010.

Kriegler, E., O’Neill, B. C., Hallegatte, S., Kram, T., Lempert, R. J., Moss, R. H., and Wilbanks, T.: The need for and use of socio-economic scenarios for climate change analysis: A new approach based on shared socio-economic pathways, Global Environ. Chang., 22, 807-822, 2012.

Lamarque, J.-F., Bond, T. C., Eyring, V., Granier, C., Heil, A., Klimont, Z., Lee, D., Liousse, C., Mieville, A., Owen, B., Schultz, M. G., Shindell, D., Smith, S. J., Stehfest, E., Van Aardenne, J., Cooper, O. R., Kainuma, M., Mahowald, N., McConnell, J. R., Naik, V., Riahi, K., and van Vuuren, D. P.: Historical (1850-2000) gridded anthropogenic and biomass burning emissions of reactive gases and aerosols: methodology and application, Atmos. Chem. Phys., 10, 7017-7039, doi:10.5194/acp10-7017-2010, 2010.

Lawson, D. R.: "Passing the test" - human-behavior and California smog check program, J. Air Waste Manage., 43, 1567-1575, 1993.

Lee, D. S., Owen, B., Fichter, C., Lim, L. L., and Dimitriu, D.: Study on the allocation of emissions from international aviation to the UK Inventory: CPEG7 Final Report to DEFRA, Global atmosphere division allocation of international aviation emissions from scheduled air traffic - present day and historical, Manchester Metropolitan University, Manchester, UK, 2005.

Lee, D. S., Fahey, D. W., Forster, P. M., Newton, P. J., Wit, R. C. N., Lim, L. L., Owen, B., and Sausen, R.: Aviation and global climate change in the 21st century, Atmos. Environ., 43, 35203537, 2009.

Lee, D. S., Pitari, G., Grewe, V., Gierens, K., Penner, J. E., Petzold, A., Prather, M. J., Schumann, U., Bais, A., Berntsen, T., Iachetti,
D., Lim, L. L., and Sausen, R.: Transport impacts on atmosphere and climate: Aviation, Atmos. Environ., 44, 4678-4734, 2010.

Levy II, H., Schwarzkopf, M. D., Horowitz, L., Ramaswamy, V., and Findell, K. L.: Strong sensitivity of late 21st century climate to projected changes in short-lived air pollutants, J. Geophys. Res., 113, D06102, doi:10.1029/2007JD009176, 2008.

Lu, Z., Zhang, Q., and Streets, D. G.: Sulfur dioxide and primary carbonaceous aerosol emissions in China and India, 1996-2010, Atmos. Chem. Phys., 11, 9839-9864, doi:10.5194/acp-11-98392011, 2011.

Maricq, M. M., Podsiadlik, D. H., and Chase, R. E.: Gasoline vehicle particle size distributions: Comparison of steady state, FTP, and US06 measurements, Environ. Sci. Technol., 33, 2007-2015, 1999.

McClintock, P.: 2007 High emitter remote sensing project, prepared for Southeast Michigan Council of Governments, Tiburon, CA, USA, available at: http://library.semcog.org/InmagicGenie/ DocumentFolder/HighEmissionsReport.pdf (last access: 4 June 2014), 2007.

McCormick, R. L., Graboski, M. S., Alleman, T. L., Alvarez, J. R., and Duleep, K. G.: Quantifying the emission benefits of opacity testing and repair of heavy-duty diesel vehicles, Environ. Sci. Technol., 37, 630-637, 2003.

Moss, R. H., Edmonds, J. A, Hibbard, K. A, Manning, M. R., Rose, S. K., van Vuuren, D. P., Carter, T. R., Emori, S., Kainuma, M., Kram, T., Meehl, G. A, Mitchell, J. F. B., Nakicenovic, N., Riahi, K., Smith, S. J., Stouffer, R. J., Thomson, A. M., Weyant, J. P., and Wilbanks, T. J.: The next generation of scenarios for climate change research and assessment, Nature, 463, 747-56, 2010.

Nakicenovic, N., Alcamo, J., Davis, G., de Vries, B., Fenhann, J., Gaffin, S., Gregory, K., Grübler, A., Jung, T. Y., Kram, T., La Rovere, E. L., Michaelis, L., Mori, S., Morita, T., Pepper, W., Pitcher, H., Price, L., Riahi, K., Roehrl, A., Rogner, H., Sankovski, A., Schlesinger, M., Shukla, P., Smith, S., Swart, R., van Rooijen, S., Victor, N., and Zhou, D.: Special report on emissions scenarios: a special report of Working Group III of the Intergovernmental Panel on Climate Change, Cambridge University Press, Cambridge, New York, 2000.

National Institute for Public Health and the Environment (RIVM): The IMAGE 2.2 Implementation of the SRES scenarios: A comprehensive analysis of emission, climate change and impacts in the 21st century [RIVM CD-ROM publication 481508018), Bilthoven, the Netherlands, 2001.

Netherlands Environmental Assessment Agency (MNP): Integrated modelling of global environmental change, An overview of IMAGE 2.4, edited by: Bouwman, A. F., Kram, T., and Goldewijk, K. K., Bilthoven, the Netherlands, 2006.

Ntziachristos, L. and Samaras, Z.: An empirical method for predicting exhaust emissions of regulated pollutants from future vehicle technologies, Atmos. Environ., 35, 1985-1999, 2001.

Ohara, T., Akimoto, H., Kurokawa, J., Horii, N., Yamaji, K., Yan, X., and Hayasaka, T.: An Asian emission inventory of anthropogenic emission sources for the period 1980-2020, Atmos. Chem. Phys., 7, 4419-4444, doi:10.5194/acp-7-4419-2007, 2007.

Olsthoorn, X.: Carbon dioxide emissions from international aviation: 1950-2050, J. Air Transp. Manag., 7, 87-93, 2001.

Owen, B. and Lee, D. S.: Allocation of international aviation emissions from scheduled air traffic-future cases, 2005 to 2050 (report 
3 of 3), study on the allocation of emissions from international aviation to the UK inventory-CPEG7, final report to DEFRA global atmosphere division, Manchester Metropolitan University, United Kingdom, 2006.

Owen, B., Lee, D. S., and Lim, L.: Flying into the future: aviation emissions scenarios to 2050, Environ. Sci. Technol., 44, 22552260, 2010.

Parks, R. W.: Durability, maintenance and the price of used assets, Econ. Inq., 17, 197-217, 1979.

Paxian, A., Eyring, V., Beer, W., Sausen, R., and Wright, C.: Present-day and future global bottom-up ship emission inventories including polar routes, Environ. Sci. Technol., 44, 13331339, 2010.

Rao, S., Riahi, K., Kupiainen, K., and Klimont, Z.: Long-term scenarios for black and organic carbon emissions, Environm. Sci., 2, 205-216, 2005.

Ribeiro, K., Kobayashi, S., Beuthe, M., Gasca, J., Greene, D., Lee, D. S., Muromachi, Y., Newton, P. J., Plotkin, S., Sperling, D., Wit, R., Zhou, P. J., Davidson, O. R., Bosch, P. R., Dave, R., and Kingdom, U.: Transport and its infrastructure, in Climate Change 2007: Mitigation. contribution of working group III to the Fourth Assessment Report of the Intergovernmental Panel on Climate Change, edited by: Metz, B., Davidson, O. R., Bosch, P. R., Dave, R., and Meyer, L. A., Cambridge University Press, Cambridge, United Kingdom and New York, NY, USA, 2007.

Saikawa, E., Kurokawa, J., Takigawa, M., Borken-Kleefeld, J., Mauzerall, D. L., Horowitz, L. W., and Ohara, T.: The impact of China's vehicle emissions on regional air quality in 2000 and 2020: a scenario analysis, Atmos. Chem. Phys., 11, 9465-9484, doi:10.5194/acp-11-9465-2011, 2011.

Sausen, R. and Schumann, U.: Estimates of the climate response to aircraft $\mathrm{CO}_{2}$ and $\mathrm{NO}_{\mathrm{x}}$ emissions scenarios, Clim. Change, 44, 27-58, 2000.

Schultz, M. and Rast, S.: Emission datasets and methodologies for estimating emissions, RETRO Rep., D1-6, Fifth Framework Programme, European Commission, Brussels, available at: http: //retro.enes.org (last access: 16 May 2013), 2007.

Shindell, D., Faluvegi, G., Walsh, M., Anenberg, S. C., Dingenen, R. V., Muller, N. Z., Austin, J., Koch, D., and Milly, G.: Impacts of tighter vehicle-emission standards, Nature Climate Change, 1 , 59-66, 2011.

Smit, R. and Bluett, J.: A new method to compare vehicle emissions measured by remote sensing and laboratory testing: highemitters and potential implications for emission inventories, Sci. Total Environ., 409, 2626-2634, 2011.

Smith, S. J.: Income and pollutant emissions in the ObjECTS MiniCAM model, J. Environ. Dev., 14, 175-196, 2005.

Smith, S. J. and Wigley, T. M. L.: Multi-gas forcing stabilization with Minicam, Energy J., Special Issue, 373-392, 2006.

Smith, S. J., Pitcher, H., and Wigley, T. M. L.: Future sulfur dioxide emissions, Clim. Change, 73, 267-318, 2005.

Smith, S. J., van Aardenne, J., Klimont, Z., Andres, R. J., Volke, A., and Delgado Arias, S.: Anthropogenic sulfur dioxide emissions: 1850-2005, Atmos. Chem. Phys., 11, 1101-1116, doi:10.5194/acp-11-1101-2011, 2011.

Streets, D. G., Bond, T. C., Lee, T., and Jang, C.: On the future of carbonaceous aerosol emissions, J. Geophys. Res., 109, D24212, doi:10.1029/2004JD004902, 2004.
Streets, D. G., Yan, F., Chin, M., Diehl, T., Mahowald, N., Schultz, M., Wild, M., Wu, Y., and Yu, C.: Anthropogenic and natural contributions to regional trends in aerosol optical depth, 1980-2006, J. Geophys. Res., 114., D00D18, doi:10.1029/2008JD011624, 2009.

Subramanian, R., Winijkul, E., Bond, T. C., Thiansathit, W., Kim Oanh, N. T., Paw-armart, I., and Duleep, K. G.: Climate-relevant properties of diesel particulate emissions: results from a piggyback study in Bangkok, Thailand, Environ. Sci. Technol., 43, 4213-4218, 2009.

Ubanwa, B., Burnette, A., Kishan, S., and Fritz, S. G.: Exhaust particulate matter emission factors and deterioration rate for in-use motor vehicles, J. Eng. Gas Turb. Power, 125, 513-523, 2003.

Uherek, E., Halenka, T., Borken-Kleefeld, J., Balkanski, Y., Berntsen, T., Borrego, C., Gauss, M., Hoor, P., Juda-Rezler, K., and Lelieveld, J.: Transport impacts on atmosphere and climate: Land transport, Atmos. Environ., 44, 4772-4816, 2010.

Unger, N., Bond, T. C., Wang, J. S., Koch, D. M., Menon, S., Shindell, D. T., and Bauer, S.: Attribution of climate forcing to economic sectors., P. Natl. Acad. Sci. USA, 107, 3382-3387, 2010.

United Nations Framework Convention on Climate Change (UNFCCC): Updated UNFCCC reporting guidelines on annual inventories, available online at: http://unfccc.int/resource/docs/ 2006/sbsta/eng/09.pdf (last access: December 2013), 2006.

US Energy Information Administration (EIA): Annual energy review, available at: http://www.eia.doe.gov (last access: 16 May 2013), 2012.

US Environmental Protection Agency (US EPA): Calculation of age distributions in the nonroad model: growth and scrappage, EPA420-P-04-007, NR-007c, 2005.

US Environmental Protection Agency (US EPA): Development of emission rates for heavy-duty vehicles in the motor vehicle emissions simulator (Draft MOVES2009), EPA-420-P-09-005, 2009.

US Environmental Protection Agency (US EPA): Median life, annual activity, and load factor values for nonroad engine emission modeling, EPA-420-R-10-016, NR-005d, 2010a.

US Environmental Protection Agency (US EPA): Exhaust and crankcase emission factors for nonroad engine modeling compression-ignition, EPA-420-R-10-018, NR-009d, $2010 \mathrm{~b}$.

US Environmental Protection Agency (US EPA): Nonroad sparkignition engine emission and deterioration factors, EPA-420-R10-020, NR-011d, 2010c.

US Environmental Protection Agency (US EPA): Development of emission rates for light-duty vehicles in the motor vehicle emissions simulator (MOVES2010), EPA-420-R-11-011, 2011.

US Environmental Protection Agency (US EPA): AP-42: Compilation of air pollutant emission factors. Appendix H: Highway mobile source emission factors tables, available at: http://www.epa. gov/oms/models/ap42/ap42-h1.pdf (last access: 16 May 2012), 2012a.

US Environmental Protection Agency (US EPA): Emission standards reference guide, available at: www.epa.gov/otaq/standards/ nonroad/index.htm (last access: January 2012), 2012b.

van Aardenne, J. A., Carmichael, G. R., Levy II, H., Streets, D., and Hordijk, L.: Anthropogenic $\mathrm{NO}_{\mathrm{x}}$ emissions in Asia in the period 1990-2020, Atmos. Environ., 33, 633-646, 1999.

van Vuuren, D. P., Eickout, B., Lucas, P. L., and Den Elzen, M. D. G.: Long-term multi-gas scenarios to stabilise radiative forcing 
- Exploring costs and benefits within an integrated assessment framework, Energy J., Special Issue, 1-55, 2006.

van Vuuren, D. P., Edmonds, J., Kainuma, M., Riahi, K., Thomson, A., Hibbard, K., Hurtt, G. C., Kram, T., Krey, V., Lamarque, J.F., Masui, T., Meinshausen, M., Nakicenovic, N., Smith, S. J., and Rose, S. K.: The representative concentration pathways: an overview, Clim. Change, 109, 5-31, 2011.

van Vuuren, D., Riahi, K., Moss, R., Edmonds, J., Allison, T., Nakicenovic, N., Kram, T., Berkhout, F., Swart, R., Janetos, A., Rose, S. K., and Arnell, N.: A proposal for a new scenario framework to support research and assessment in different climate research communities, Global Environ. Chang., 22, 21-35, 2012.

Vedantham, A. and Oppenheimer, M.: Long-term scenarios for aviation: Demand and emissions of $\mathrm{CO}_{2}$ and $\mathrm{NO}_{\mathrm{x}}$, Energ. Policy, 26, 625-641, 1998.

Wang, M., Huo, H., Johnson, L., and He, D.: Projection of Chinese motor vehicle growth, oil demand, and $\mathrm{CO}_{2}$ emissions through 2050, ANL/ESD/06-6, Argonne National Laboratory, Argonne, USA, 2006.

Wang, X., Westerdahl, D., Wu, Y., Pan, X., and Zhang, K. M.: Onroad emission factor distribution of individual diesel vehicles in and around Beijing, China, Atmos. Environ., 45, 503-513, 2011.

Yan, F., Winijkul, E., Jung, S., Bond, T. C., and Streets, D. G.: Global emission projections of particulate matter (PM): I. Exhaust emissions from on-road vehicles, Atmos. Environ., 45, 4830-4844, 2011.
Yan, F., Winijkul, E., Bond, T. C., and Streets, D. G.: Global emission projections of particulate matter (PM): II. Uncertainty analyses of on-road vehicle exhaust emissions, Atmos. Environ., 87, 189-199, 2014.

Yanowitz, J., McCormick, R. L., and Graboski, M. S.: In-use emissions from heavy-duty diesel vehicles, Environ. Sci. Technol., 34, 729-740, 2000.

Zhang, Q., Streets, D. G., Carmichael, G. R., He, K. B., Huo, H., Kannari, A., Klimont, Z., Park, I. S., Reddy, S., Fu, J. S., Chen, D., Duan, L., Lei, Y., Wang, L. T., and Yao, Z. L.: Asian emissions in 2006 for the NASA INTEX-B mission, Atmos. Chem. Phys., 9, 5131-5153, doi:10.5194/acp-9-5131-2009, 2009.

Zhang, Y., Stedman, D. H., Bishop, G. A., Guenther, P. L., and Beaton, S. P.: Worldwide on-road vehicle exhaust emissions study by remote-sensing, Environ. Sci. Technol., 29, 2286-2294, 1995.

Zhang, Y., Karamchandani, P., Glotfelty, T., Streets, D. G., Grell, G., Nenes, A., Yu, F.-Q., and Bennartz, R.: Development and initial application of the global-through-urban weather research and forecasting model with chemistry (GU-WRF/Chem), J. Geophys. Res., 117, D20206, doi:10.1029/2012JD017966, 2012.

Zhao, Y., Nielsen, C. P., Lei, Y., McElroy, M. B., and Hao, J.: Quantifying the uncertainties of a bottom-up emission inventory of anthropogenic atmospheric pollutants in China, Atmos. Chem. Phys., 11, 2295-2308, doi:10.5194/acp-11-2295-2011, 2011. 